\title{
Governmental Structure of the Russian Federation with Respect to Environmental and Energy Programs
}

by R.V. Colangelo," E.L. Reistroffer," and D.E. Edgar

Energy Systems Division, Argonne National Laboratory, 9700 South Cass Avenue, Argonne, Illinois 60439

September 1992

Work sponsored by United States Department of Energy, Office of Environmental Restoration and Waste Management

"Colangelo and Reistroffer are affiliated with the Environmental Planning Group, Inc., Elk Grove Village, Illinois.

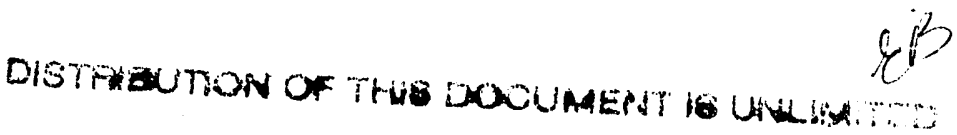




\section{Preface}

Information contained in this report was provided to Argonne National Laboratory under contract No. 20082402 by R.V. Colangeio and E.L. Reistroffer, employees of the Environmental Planning Group, Inc., 1822 Elmhurst Road, Elk Grove Village, Illinois 60007, telephone 708-437-8001. 


\section{Contents}

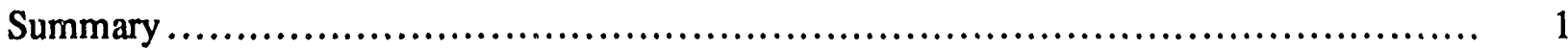

1 Purpose of the Investigation........................................................... 3

2 Scope of Services and Limitations of the Investigation ............................ 4

3 Factors Affecting Environmental and Energy Programs ............................ 6

3.1 Legacy of Communism ..................................................... 6

3.2 International Funding ................................................................... 7

3.3 Status of Scientists ......................................................... 7

3.4 International Agreements ..................................................... 7

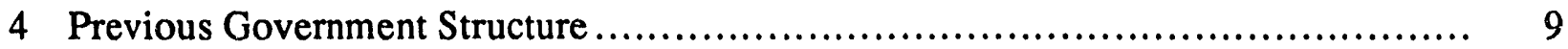

4.1 Political Structure of the USSR prior to Reforms.................................. 9

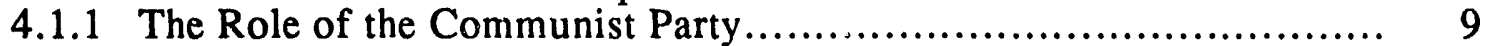

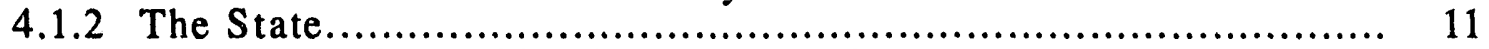

4.2 Political Structure of the USSR during Perestroika ......................... 12

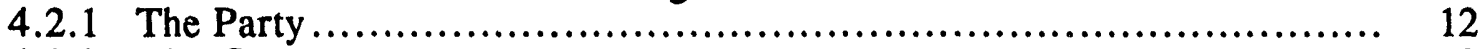

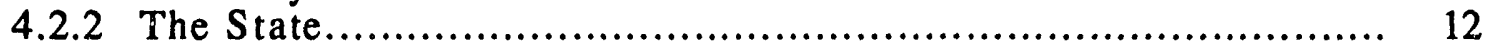

5 Current Structure of the Government of the Russian Federation....................... 16

5.1 The Presidential Apparatus .......................................................... 16

5.2 Ministries and State Committees ................................................ 19

6 Organization of the Russian Academy of Sciences and Other

Research Institutes ............................................................ 25

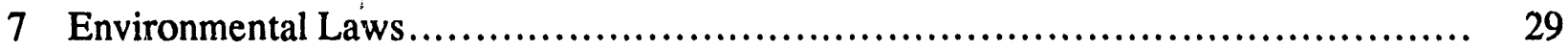

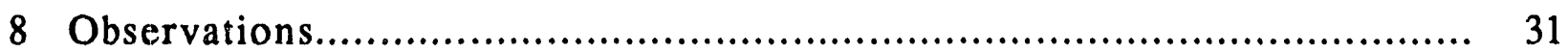

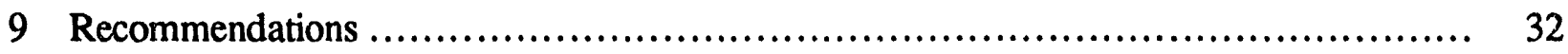

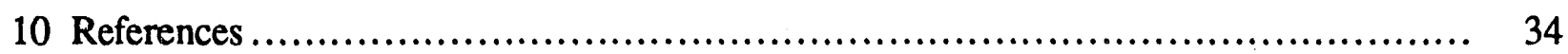

Appendix A: Bilateral Agreement on Cooperation in the Field of Environmental Protection .................................................................. 37

Appendix B: Decree of the President of the Russian Federation Concerning Measures for the Reorganization of the Structure of the Apparatus of the President of the Russian Federation

Appendix C: Prominent Members of the Committee of Fifteen Environmental Specialist Advisors 


\section{Contents (Cont.)}

Appendix D: Disposition of the President of the Russian Federation Concerning the Formation of a Coordinating Committee on Ecological Policy under the President of the Russian Federation

Appendix E: Position Concerning the Coordinating Council on Ecological Policy under the President of the Russian Federation

Appendix F: Government of the Russian Federation Resolution, 7 July 1992, No. 468, Concerning the Specially Authorized Organs of the State Government in the Field of Environmental Protection

Appendix G: Main Offices of the Ministry of Ecology and Natural Resources

Appendix H: Law of the Russian Soviet Federal Socialist Republic Concerning the Preservation of the Surrounding Natural Environment

Figures

1 Territory of the Former Soviet Union

2 Higher Bodies of State Authority and Administration of the USSR prior to Reforms.

3 Higher Bodies of State Authority and Administration of the USSR Reflecting the Reforms of Perestroika and Recent Constitutional Amendments....

4 Structure of Russian Environmental Programs in the Executive Branch of the Russian Federation Governmen

5 Structure of the Ministry of Ecology and Natural Resources

6 Main Offices of the Ministry of Ecology and Natural Resources

7 Structure of the Ministry of Atomic Energy

8 Structure of the Russian Academy of Sciences

9 Structure of the Institute of Nuclear Safety, Russian Academy of Sciences 


\title{
Governmental Structure of the Russian Federation with Respect to Environmental and Energy Programs
}

\author{
by \\ R.V. Colangelo, E.L. Reistroffer, \\ and D.E. Edgar
}

\section{Summary}

An investigation was conducted by the Environmental Planning Group, Inc., to provide an overview of the structure of government environmental and energy programs in the Russian Federation. The investigation was undertaken to provide a baseline of information to the U.S. Department of Energy (DOE), so that technologies applicable to DOE environmental restoration and monitoring programs can be identified, tested, and transferred.

Data for the report were collected through a network of Russian and American sources knowledgeable about environmental and energy programs in the ussian Federation. Sources of information included both U.S. and Russian government personnel, nongovernmental organizations, private consultants, and experts from the academic and scientific communities.

The peculiarities of the Union of Soviet Socialist Republics (USSR) remain prevalent in the structure of the Newly Independent States, especially in Russia. The legacy of communism is visible in all aspects of society, most particularly in the extreme environmental degradation that has resulted from careless central planning and policies of forced industrialization.

The structure of the USSR government in the past appeared to be a branch system with legislative, executive, and judicial organs. True power, however, was held by the Communist party, which dictated policy and held all strategic government positions. The dominance of the party negated any separation of powers within the government. Reforms initiated under Mikhail Gorbachev during the period of Perestroika were aimed at shifting power from the party to the respective government organs. Following an unsuccessful coup attempt in August 1991, the USSR was officially disbanded in early 1992. The Commonwealth of Independent States was then created, joining 11 of the 15 republics into a loose federation.

The investigation undertaken by the Environmental Planning Group, Inc., focused on the executive organs of the present Russian government in an effort to define key ministries with environmental and energy responsibilities. The structure of the Ministry of Ecology and Natural Resources (Minpriroda) and the Ministry of Atomic Power (Minatom) are presented. The Academy of Sciences and other ministries that have relevance to the transfer of technologies are 
also discussed. In addition, research institutions in which technologies appropriate to DOE programs are likely to reside are identified.

This investigation is considered part of an ongoing analysis of the evolving structure of the Russian Federation. The organizational flow charts and supporting documentation presented in this report provide only an initial understanding of the structure of the Russian government. This report is not intended to be an exhaustive review, but to serve as a baseline investigation for future work. Information contained in this report is current as of July 1992. The reader should determine whether developments have occurred that make this material outdated."

* For instance, the Ministry of Ecology and Natural Resources is now known as the Ministry of Environmental Protection and Natural Resources. 


\section{Purpose of the Investigation}

The purpose of this investigation is to define the present structure of the Russian Federation government, and in particular, to determine the organization of Russian environmental and energy programs. This information will assist in the identification of innovative environmental and energy technologies and in the development of effective mechanisms for technology transfer.

Argonne National Laboratory (ANL) contracted for this investigation with the Environmental Planning Group, Inc. (EPG), in order to support the environmental initiatives and activities of the U.S. Department of Energy (DOE) in the Former Soviet Union (FSU). The DOE is committed to cooperation with the FSU, especially in nuclear-related fields and environmental remediation, and supports U.S. government policy objectives in this region. These objectives include encouraging the political and economic stability of the FSU and Russia, the conversion of military facilities to civilian activities, development of opportunities for nuclear scientists, and the dismantlement of nuclear weapons.

The DOE's Office of Environmental Restoration and Waste Management (EM) has responsibility for addressing the waste management and environmental remediation problems resulting from U.S. nuclear weapons production activities. A cooperative technology identification and transfer program between DOE-EM and Russia would allow tie. United States to supplement its technology development program with the advances made by Russian researchers who have been addressing similar problems. The identification and development of Russian technologies applicable to DOE-EM problems would further U.S. policy goals by engaging Russian scientists, by providing needed resources to the Russian economy through the adaptation of available technologies, and by establishing a strong cooperative relationship with Russian counterparts active in nuclear fields. Russian waste management and environmental remediation problems may also be alleviated by U.S. technologies. This report will assist in implementing these interests. 


\section{Scope of Services and Limitations of the Investigation}

The EPG provided the following services:

- Researched available literature pertaining to environmental concerns in the USSR and the newly created Russian Federation.

- Created a network of knowledgeable sources. Sources included U.S. and Russian grass-roots groups, nongovernmental organizations, government agencies, private industry, and academics who had access to specialized information and practical knowledge of the Russian system. Networking was facilitated through the use of electronic mail, participation in ECONET (a service of the Institute for Global Communications), membership in the International Clearinghouse on the Environment, and contacts with the Institute for Soviet-American Relations.

- Developed an office in Moscow staffed with indigenous personnel having environmental and energy expertise.

- Conducted field research in the United States, interviewing key government and scientific personnel involved in Russian activities.

- Conducted two site visits to Russia. Representatives from EPG interviewed key personnel, collected data, and became familiar with current business practices.

- Validated the information collected with the help of Russian environmental scientists.

- Identified the most current body of environmental laws in the Russian Federation.

- Compiled a draft report, presented the report for client comments, and validated the report during a return trip to Russia.

- Compiled a final report summarizing the investigation.

The information contained in this report was collected from September 1991 through July 1992 and represents an overview of the various Russian energy and environmental programs. The 
structure of the Russian government continues to change at all levels, and a definitive statement of organizational and administrative form is impossible at this time.

Throughout the duration of the project, EPG employed a flexible approach that allowed appropriate response to the changing political situation in Russia. The focus of the investigation was continually evaluated. As collected information began to indicate that energy and environmental technology would not be easily accessed through the upper echelons of the various Russian ministries or government officials, EPG redirected its efforts. The most promising research institutes and the Academy of Sciences, where specific environmental and energy technologies reside, were identified for future investigation.

In Russia, no established format exists for communicating the status of government programs or legislation. There is no official record-keeping system that is available to the public or is even Iu dily accessible to government officials. Russian bureaucracy is entrenched in the closed operations of its communist heritage, anc information dots not flow freely. Confusion and uncertainty regarding current structure was evident among all Russian sources available to EPG.

The collapse of the USSR has created an unstable political climate for the Newly Independent States and inspired a reevaluation of past restrictive measures. This situation allowed EPG to access data that was once considered sensitive or classified. Project budget and time constraints, however, limited EPG's ability to identify, collect, and verify all information. This report presents a limited overview of the structure of the government, not an exhaustive review and compilation. 


\section{Factors Affecting Environmental and Energy Programs}

The peculiarities of the USSR reinain prevalent in the structure of the independent states, especially in Russia. Government and civil organizations reflect the long history of central planning, forced industrialization, obsession with defense and national security, and restricted access to information. Moscow, once the nucleus of the centralized Soviet government, still controls much of the governmental infrastructure of the previous regime. Moscow is also the most burdened by the legacy of communism and its administrative bureaucracy.

\subsection{Legacy of Communism}

Communism's centrally planned economy created state monopolies that today are reluctant to relinquish their privileged position. Propaganda that glorified labor and progress promoted a policy of forced industrialization that began in the 1920s. Economic policies led to undervalued natural resources and disregard for environmental safeguards (Gelb and Grey 1991). The emphasis on industry was coupled with artificially low energy prices for high-sulfur coal and other highly polluting sources. The absence of competition and the assurance of state subsidies created a powerful production complex that continues to wield its power and resist environmental regulation.

Valovaya produktsiya, the Russian term for gross output, was the guiding principle of the Soviet economy and the ultimate measure of growth and progress (Feshbach and Friendly 1992, p. 40). Dictated by central planners who were removed from expert counsel and oblivious to market mechanisms, production goals and five-year plans taxed the resources of the USSR but seldom satisfied the real needs of the population. Industry used two-thirds of all energy produced in the USSR in 1985 (Feshbach and Friendly 1992, p. 141), a testament to its inefficiency as much as to its dominance in Soviet society.

An obsession with defense created a military-industrial complex that was given priority over all other considerations, including ecological concerns. The deepest fresh water lake in the world, Lake Baikal, which is situated in one of the most pristine areas of Siberia, is threatened by industrial development. The decision in 1957 to locate a plant for the production of a new durable cord in this region reveals a fundamental principle of the Soviet system. Critics failed to halt the building of the plant (scientists and authoritative national institutes representing many different fields protested against the project) because the cord was needed by the Ministry of Defense for heavy bomber tires. This plant was being built for the "strategic interests of the country;" thus, the plans could not be challenged (Feshbach and Friendly 1992, p. 117). This information was not made public during the debate.

The environmental degradation within the confines of the territory of the Former Soviet Union (FSU) was a guarded secret of the Communist regime. Today, the ecological disasters of 
Russia and the Commonwealth of Independent States (CIS) are a dominant topic in the press (Feshbach and Friendly 1992; U.S. News and World Report 1992).

\subsection{International Funding}

As the United States and the world react to these revelations, billions of dollars are being channeled to the FSU. The United States alone has pledged an aid package of over $\$ 6$ billion. The International Monetary Fund, the European Bank for Reconstruction and Development, the International Finance Corporation, and the U.S. Agency for International Development are among the host of international development funds that have recently embraced Russia and the CIS. The World Bank, which now maintains a strict environmental assessment requirement with any major project (World Bank 1991), has also extended its funding to the Newly Independent States. Appropriate distribution of funding will require a practical knowledge of the structure and organization of the present State and the scientific community.

As Russia becomes a recipient of these funds, environmental investigations and remediation will be recognized as priorities. The need for testing and implementation of environmental technologies will be paramount.

\subsection{Status of Scientists}

Russian scientists are especially affected by the recent political and economic changes. Traditionally supported by the military-industrial complex, researchers find their livelihood threatened as the ecnnomy is restructured. Full members of the Academy of Sciences, the most prestigious scientific organization in Russia, earn less than a bus driver (Feinberg 1992). "Brain drain," the migration of trained scientists to other occupations or other countries, is seriously affecting the operations of research institutes (Sagdeev 1992, Feinberg 1992).

The association of technology development with the military-industrial complex reinforces the lingering Soviet tendency to secrecy and the reluctance to share information. In addition, opportunism is rampant throughout all sectors of society as the need for hard currency increases. Any attempt to identify and transfer technologies must not only penetrate the remaining barriers of the Soviet military complex, it must also negotiate the competitive capitalistic spirit that is thriving, even in scientific communities.

\subsection{International Agreements}

In 1972 the United States and the USSR signed an agreement entitled, "Cooperation in Environmental Protection." The Joint Committee on Cooperation held its 14th meeting in 
Washington, D.C., May 11-15, 1992. The U.S. Environmental Protection Agency (EPA), which administers this agreement in the United States, claims that the document will now stand as a multilateral agreement extending to the 11 members of the CIS. The Russian Federation, however, maintains the strongest ties and participation. Appendix A lists the areas of cooperation defined by this bilateral agreement and the U.S. agencies that administer the corresponding working groups. Also included in Appendix A is a listing of key U.S. personnel active in the working groups.

Historically, the focus of this agreement has been scientific and technical exchanges, to the neglect of policy and regulatory concerns. While this emphasis may be changing - especially due to the recent inclusion of nongovernmental organizations as a working group on the Joint Committee - a history of scientific and technical cooperation has been established.

Cooperation administered at the State level has also been complemented by more specific agreements. The Department of Energy, for instance, has negotiated directly with the Ministry for Atomic Power and Industry (once known as MAPI but now succeeded by Minatom, or the Ministry of Atomic Energy). The following agreements are in effect: Cooperation in the Field of Peaceful Uses of Atomic Energy (1973, revised 1990) and Cooperation in the Fields of Environmental Restoration and Waste Management (1990). Other U.S. agencies administering bilateral agreements with the FSU include National Aeronautics and Space Administration, Department of Health and Human Services, National Oceanic and Atmospheric Administration, Department of Agriculture, Office of Science and Technology Policy, and Department of Transporiation. 


\section{Previous Government Structure}

A map of Russia and the territory of the FSU is presented in Figure 1. This report will focus on the Russian Federation. The present political structure, however, must be understood in the context of the radical transformations that have characterized the recent history of this region. The following discussion of political structure in the USSR draws heavily on the analysis of Barry and Barner-Barry $(1987,1991)$. Ultimately, the unique history, highly developed hierarchy, and administrative emphasis of the USSR will influence and shape the structure of the independent states.

\subsection{Political Structure of the USSR prior to Reforms}

The political structure of the USSR consisted of an apparent branch system of government. The Supreme Soviet was the mandated legislative branch, the Supreme Court and Procuracy were responsible for judicial functions, and the Council of Ministers held executive powers and was responsible for the administration of the All-Union Ministries, State Committees, and the Union Republic Ministries. Overseeing these branches, however, was the strong arm of the Communist party, which effectively negated any pretense of checks and balances. Moscow was the political and administrative center of the USSR.

A simplified overview of the political structure of the Soviet Union as it existed prior to 1985 and the reforms of Perestroika is presented in Figure 2.

\subsubsection{The Role of the Communist Party}

Although the hierarchy of the Communist party remained distinct from the hierarchy of the State, all policy and power were centered in the party apparatus.

The Congress, the designated "supreme organ" of the party, was a convocation of delegates drawn from party organizations at all levels throughout the Union. The convocation typically took place every five years, serving as a forum for the presentation of party programs. Its primary function was the election of members to the Central Committee. This was a purely ceremonial function, and the Congress was without any real political power.

The mandate of the Central Committee was to direct the activities of the party between Congresses. Meetings, which lasted one day and were known as plenary sessions, were only held about every six months. The Central Committee, therefore, was not influential in actually forming policy and directing the activities of the party, but was a highly symbolic gathering of the most influential party leaders. Its membership was under 500 and was the "pool" from which top party 


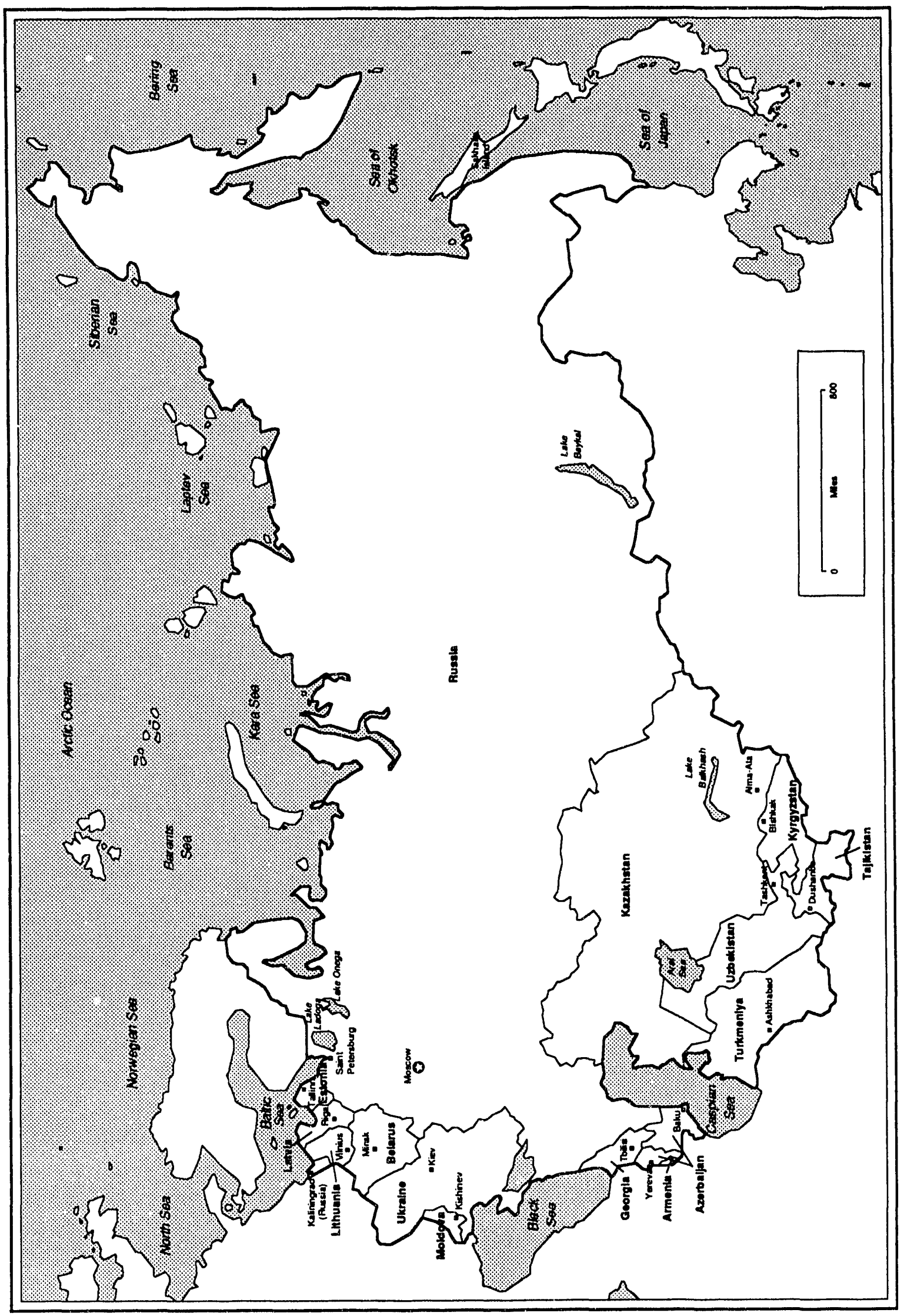

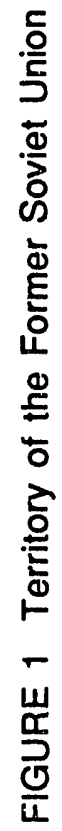




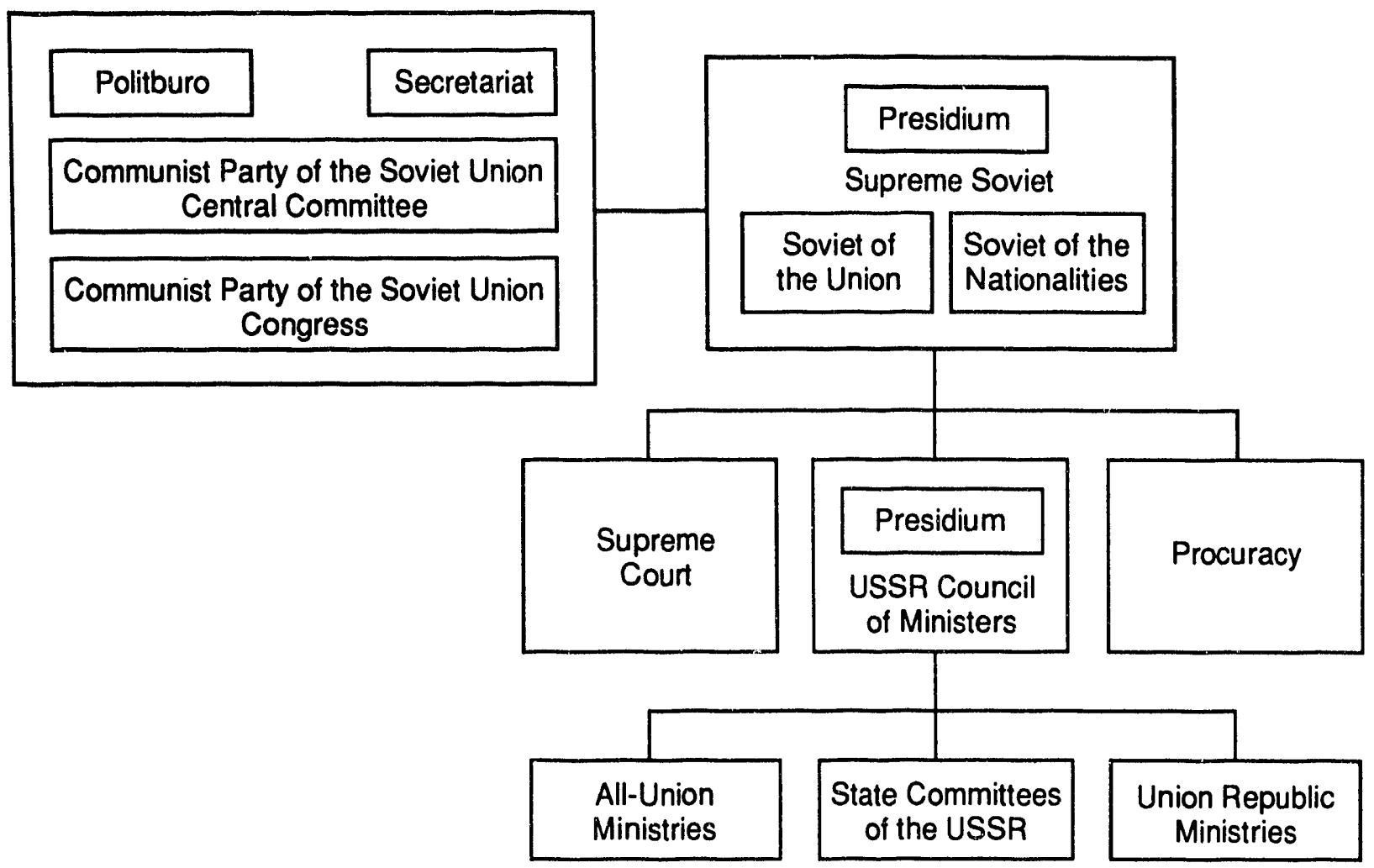

FIGURE 2 Higher Bodies of State Authority and Administration of the USSR prior to Reforms

leadership was drawn. The Central Committee was charged with electing members to the Politburo and the Secretariat, the true centers of power in the Communist system.

The Politburo, an elite group of about 20 individuals, acted as the true policy-making body of the party. The Politburo met about once a week to discuss policy issues and usually reached full consensus in decisions. The Secretariat, a bureaucracy that contained as many as several hundred thousand officials, was the administrative body. The most powerful position of the USSR was the General Secretary, or leader of the Secretariat. The General Secretary was usually a member of the Politburo and its de facto leader. The Secretariat leadership also held weekly meetings, in which they supervised essentially all aspects of life in the Soviet Union.

\subsubsection{The State}

The Supreme Soviet was described in the Constitution of the USSR (Article 108) as "the highest body of state authority" and functioned as the legislative branch of the government. The Supreme Soviet was composed of two houses, the Soviet of the Union and the Soviet of the Nationalities. Each of these houses had 750 members, the latter house elected from national territorial units, the former house from units based on population size. Membership in the Supreme Soviet was primarily an honorary position, whose purpose was to participate in a 
ceremonial ratification process for party policy. The Supreme Soviet met for only a few days each year.

The Presidium of the Supreme Soviet, a 36-member, continually functioning legislature, actually performed the bulk of the lawmaking duties. The chairman of the Presidium was usually a member of the Politburo and an effective instrument of party policy.

The Council of Ministers was appointed by and accountable to the Supreme Soviet. The Constitution designated the Council of Ministers as the "executive organ" of government, but any real influence resided in the Presidium of the Council, a select group of experienced leaders typically chosen from top-ranking party members. State Committees were also positioned at the ministerial level, and the chairmen of these committees held rank comparable to the Ministers.

The Supreme Court and the Procuracy made up the judicial branch of the Soviet government. The Procurr.cy, headed by the Procurator General and overseeing a vast network of local offices, supervised the execution of Soviet laws. The Supreme Court, represented at the union and republican levels, heard appeals from lesser courts and prepared guiding statements on interpretation of law.

\subsection{Political Structure of the USSR during Perestroika}

The political structure of the USSR under Mikhail Gorbachev, reflecting reforms instituted during the period of Perestroika and the amendments to the Constitution enacted in 1988, 1989, and 1990, is presented in Figure 3. Under Gorbachev, political reform foused on reducing the party bureaucracy and transferring real authority to the government organs.

\subsubsection{The Party}

The hierarchy of the Communist party remained intact throughout much of the period of Perestroika, but the power of the party was undermined by the reforms. This change was achieved primarily through the creation of a democratically elected legislature.

\subsubsection{The State}

The newly designed legislative branch of the USSR consisted of the Congress of People's Deputies, consisting of 2,250 democratically elected members, and the Supreme Soviet, consisting of 542 members chosen from the Congress. Under reforms instituted in 1988, the Constitution (Article 108) designated the Congress of People's Deputies as the "highest organ of state power." 


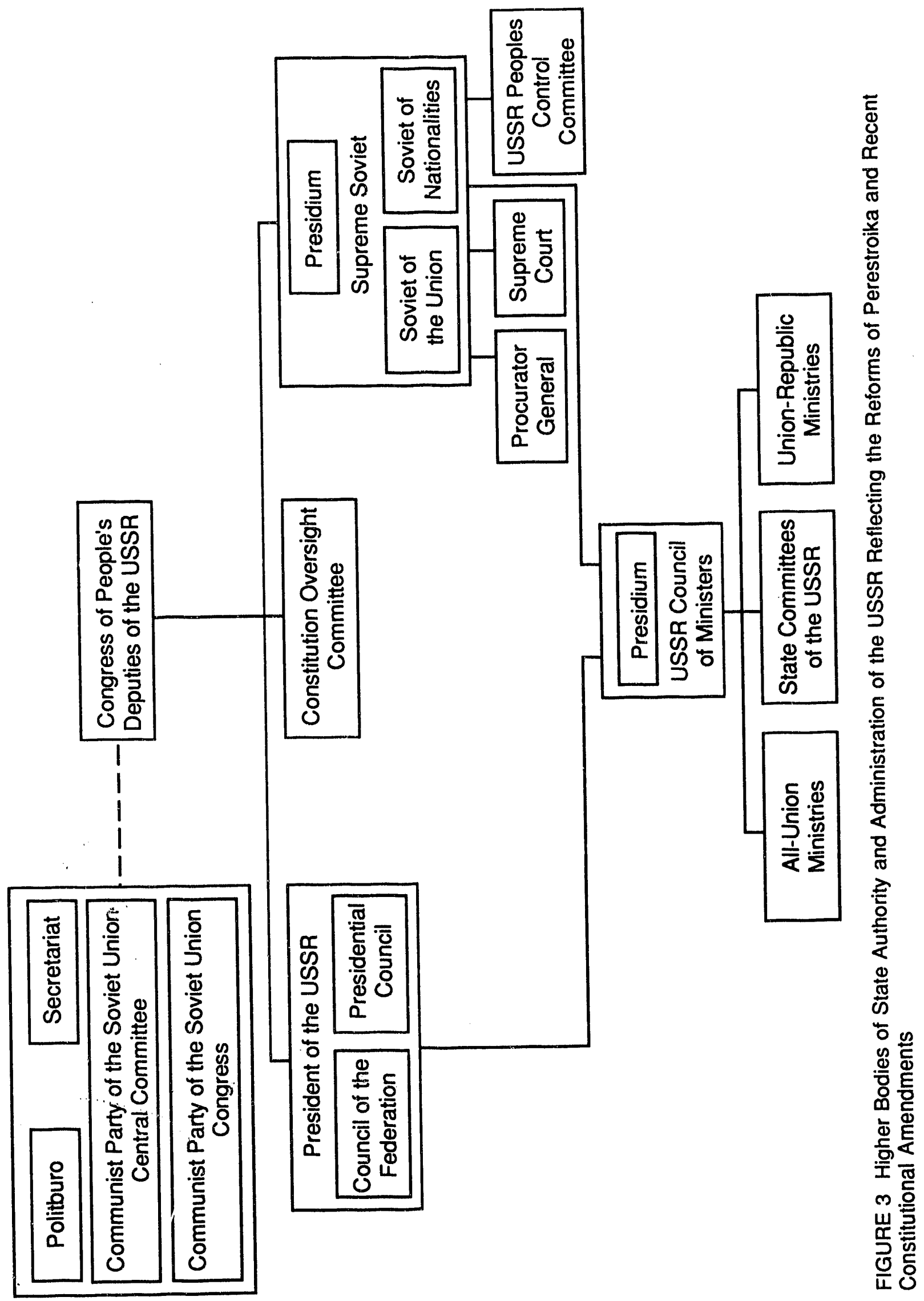


The Supreme Soviet was restructured to be a continuously functioning legislative body. There is no U.S. institution comparable to the Congress of People's Deputies, but in relation to the Supreme Soviet, this Congress functioned as an electoral college.

The Supreme Soviet sat for 8-10 months of the year and had the power to convene the Congress of People's Deputies, which held regular meetings at least once a year. The Chairman of the Supreme Soviet, not the Chairman of the Presidium of the Supreme Soviet, ranked in the highest position of the legislature. Until the creation of the Presidency, this position was the most important in the restructured government.

The judicial branch of the government was composed of the Supreme Court, the Procuracy, and the Constitutional Oversight Committee. The Supreme Court, like its U.S. counterpart, heard appeals from and offered guidance to lesser courts. The Procuracy provided officials to represent the accused in court and supervised compliance with the law. The Constitutional Oversight Committee was created under the 1988 reforms. It was composed of 23 specialists in the fields of law and politics chosen to monitor the correspondence between USSR law and the Constitution. Its members were elected by the Congress of People's Deputies to serve terms of 10 years. Assuring the correspondence between law and constitution is the function of the Supreme Court in the United States.

The People's Control Committee performed systematic checks to assure that party directives and Soviet laws were properly implemented. The Committee had originally used the services of volunteer citizens to undertake checks at the local levels, but it finally employed only professional inspectors.

The transfer of power to this democratic system was complete in early 1990 , when the Communist party lost its position as the sole legal political party.

The Presidency of the USSR was created by amendment to the Constitution in March 1990. The function of the Presidency is to oversee and coordinate the different branches of the government and, in particular, to act as a liaison between the executive and legislative branches. This office emerged coincident with the end to the monopoly of the Communist party and the need for a powerful political force to deal with the internal crises generated by reforms and growing ethnic unrest. Although the Constitution called for election of the president by popular vote, Gorbachev was appointed the first incumbent by the Congress of People's Deputies.

The creation of this post continued a trend toward the separation of powers within the government and was a critical move in the transfer of power from the Communist party to the state. In June 1991, Gorbachev resigned his position as Party Chairman and was granted the right to serve as both President and Prime Minister of the USSR, in an effort to administer his reforms in a more effective manner. 
The Council of Ministers was composed of representatives from the Ministries and State Committees from the all-union and union-republic levels. The Council held great policy-making power, especially in its right to issue decrees that are considered legal norms (Barry and BarnerBarry 1991). Much of this policy-making power was exercised by the Presidium of the Council.

Following an unsuccessful military coup attempt (August 1991) and the challenge to Gorbachev's leadership by popular leader Boris Yeltsin, the USSR was officially disbanded in early 1992. The Commonwealth of Independent States was created, joining 11 of the former 15 republics into a loose federation.

Russia, now an independent state under the leadership of President Boris Yeltsin, continues to maintain a position of power in administering the CIS. This position is largely due to Russia's control of bureaucratic mechanisms and command of vast resources. Most of the leading scientists and research centers are located in Russia. Russia's leading competitor in this area is Ukraine, and a mounting rivalry between these two states lends great instability to the CIS. According to Western diplomatic sources, the CIS is "largely a fiction" and is likely to disband in the near future. 


\section{Current Structure of the Government of the Russian Federation}

The political structure of the Russian Federation is undergoing constant change and reorganization, and the radical transformations have left the country in a state of uphcaval. The Communist party no longer has a formal or power relationship to the government structure and has been officially outlawed. Russian sources were unclear about government structure when reporting the information that forms the basis of this report, and EPG found considerable contradiction in the material gathered. The following summary includes the information that EPG considers most reliable. This report is not a comprehensive account of the current Russian government. It focuses on the executive branch and its associated environmental and energy programs and does not discuss the legislative and judicial branches of government.

Many of the present organs of the Russian government appear to have correspondence to previous governmental elements of the USSR. They have, however, been restructured. The fall of the Communist party from its position of supreme authority and the institution of democratically elected officials has completely altered the government system.

EPG has prepared four flow charts from originally gathered information and adapted two others from the related work of colleagues (Etkins 1992; Lehman 1990). It is important to note that flow charts and official hierarchy do not always reflect the actual chain of command in the Russian system. The position of a ministry or committee can be rendered meaningless if administrative support or funding is insufficient. EPG found that those organizations at the lower end of the hierarchy in the Russian system were able to respond most practically to policy prescriptions and exhibited the greatest degree of stability.

An overview of the current political structure of the Russian Federation, highlighting environmental programs associated with the executive branch of government, is presented in Figure 4. In this discussion, the presidential apparatus is addressed first, with attention to the advisory positions and policy-making bodies related to the environment. Next is a discussion of the ministerial level of government, with particular attention to the Ministry of Ecology and Natural Resources. The organization of the Russian Academy of Sciences (a nongovernmental organization) and other research institutes is presented in relation to current environmental programs in Russia in Section 6. A discussion of environmental law is presented in Section 7 to indicate the direction of development of the environmental industry in Russia.

\subsection{The Presidential Apparatus}

The office of President of Russia, currently held by Boris Yeltsin, continues to evolve in its function and powers. Even more recently created is the office of the Vice President, held by 


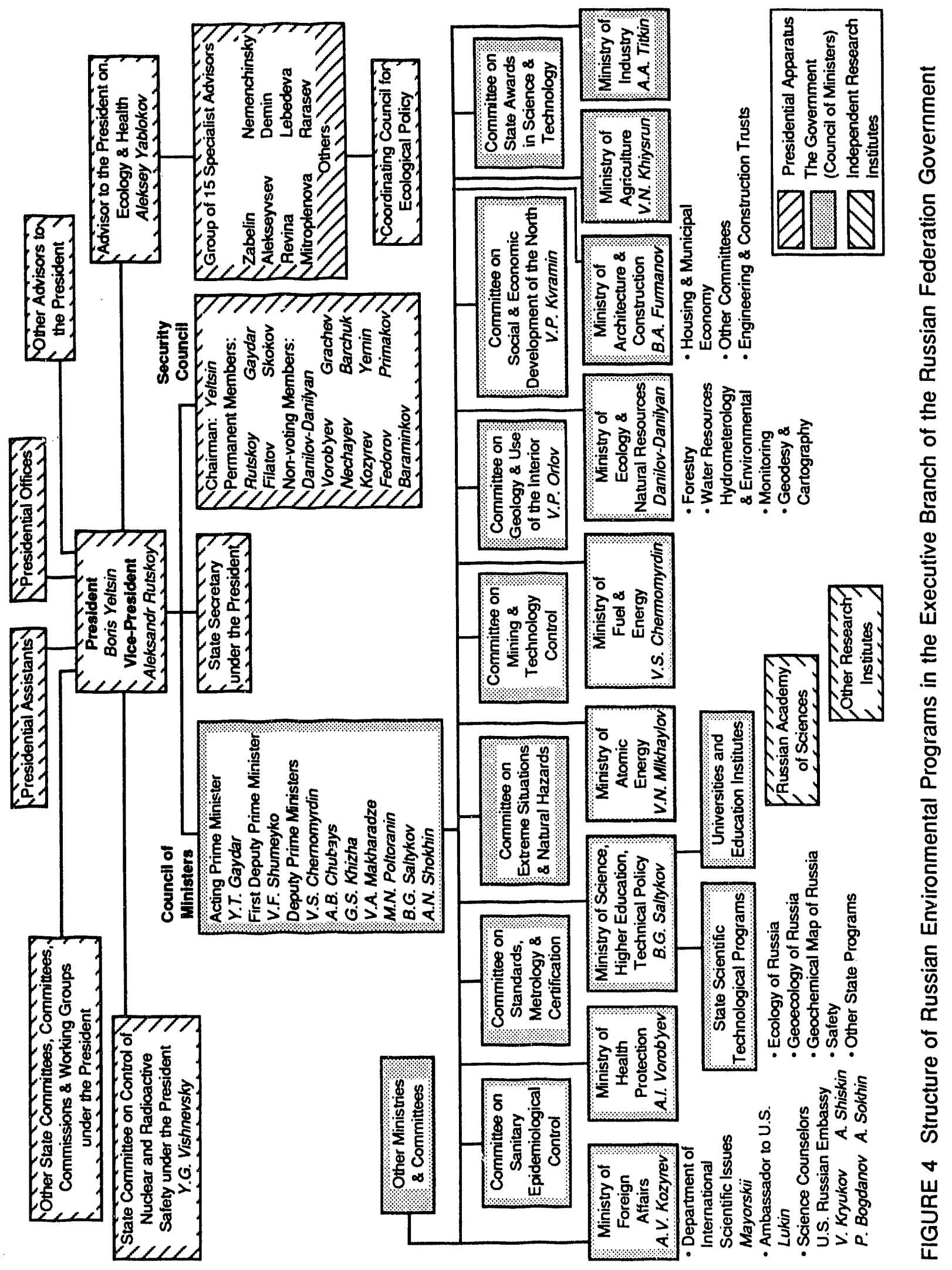


Aleksandr Rutskoy. The description of the duties of the Vice President is said to explicitly include protection of natural resources.

General restructuring to reduce the bureaucracy and to continue the transfer of authority to the actual government bodies is reflected in the Presidential Decree dated May 6, 1992. An English translation of this document is included in Appendix B. In addition to describing the various offices surrounding the president, this document identifies the position of several state committees, other committees, and commissions relevant to environmental concerns. These entities were transferred from their position within the presidential apparatus to the ministry level. It is assumed that the entities not referred to in the decree have retained their previous status. For this reason, the State Committee on Nuclear and Radioactive Safety is reflected on the structure charts at the presidential level.

The offices of Advisors to the President are positions created to address specific political needs and can be compared to the Executive Offices of the U.S. President. These positions exercise no direct administrative power. Reportedly, there exist about 10 advisors to the president, although the decree dated May 6,1992, authorizes only five such positions.

Aleksey Yablokov is the Advisor to the President on Ecology and Health. Michael Deland, Chairman of the U.S. Council on Environmental Quality, holds an analogous position. Yablokov is a distinguished biologist in the Academy of Sciences and longtime environmental activist. In addition to his advisory role, Yablokov serves in the Congress of People's Deputies as an elected official. As part of his congressional responsibilities, Yablokov also acts as deputy chair of the Supreme Soviet Committee on Ecology and the Rational Use of Natural Resources. In this capacity, he is influential in drafting new environmental laws. Besides holding governmental posts, Yablokov is president of the Russian chapter of Greenpeace. He is the most important personality in the environmental movement in Russia (Green 1990).

In his position as Advisor to the President, Yablokov is assisted by a group of 15 environmental specialists. Composition of this body is said to "change every day." A listing of the most stable and prominent members is included as Appendix C.

The government agencies that deal with environmental issues coordinate their activities by participation in a "roundtable" known as the Coordinating Council for Ecological Policy. This council was signed into effect by Yeltsin on January 4, 1992. Translations of the documents relating to the formation of the coordinating council and its function are included in Appendixes D and $E$. Seventeen agencies from all levels of government are represented on the council. Although the council has no direct administrative influence, it can provide a forum for policy development. There is some skepticism regarding the need for and the potential effectiveness of such a council. This coordinating council is analogous to an interagency working group of the U.S. government.

A Security Council with membership drawn primarily from the Cincil of Ministers is headed by the president. The council examines domestic, foreign, and defense policy; declares or 
lifts a state of emergency, as required; drafts decrees on security issues; issues proposals for the activities of the executive bodies; and creates interagency commissions to study specific security problems, as necessary (Central Intelligence Agency 1992). The Ministers of Ecology and Natural Resources (Danilov-Danilyan) and Health Protection (Vorob'yev) currently serve on this council. The National Security Council in the U.S. government is a direct parallel with the Russian Security Council.

\subsection{Ministries and State Committees}

The ministries, state committees, and associated administrative organs are commonly referred to as the government. The Prime Minister (also known as Premier or Chairman) is the head of government and oversees the day-to-day administration of the ministries. There is no exact analogy for this position in the U.S. government. It most closely resembles the same position in a parliamentary system.

Yegor Timurovich Gaydar is acting Prime Minister. Gaydar was nominated by Yeltsin because of his commitment to economic reforms, but his final confirmation by the Congress may encounter difficulties from conservative members. In his previous position as Deputy Prime Minister, Gaydar held jurisdiction over the Ministry of Ecology and Natural Resources. Vladimir Shumeyko, Coordinator of the Branches of the National Economy, was appointed First Deputy: Prime Minister as of June 2, 1992.

At present there are approximately 25 ministries - analogous to U.S. cabinet positions in the Russian government, as compared with over 100 ministries in the USSR prior to reforms. The ministries listed in Figure 4 are those most often associated with environmental concerns. The ministries appear to be the government offices most encumbered by the inefficiencies of the old Soviet system. In the old structure, ministries were part of a commanding administrative system and only lately have been recognized as organizations that actually carry out work or projects.

The leadership of the Council of Ministers is composed of the prime minister, first deputy prime minister, and deputy prime ministers. At present there are nine members of this group. Several of the deputy prime ministers also oversee particular committees or sectors of government. Chernomyrdin is involved in the Fuel and Energy Complex; Khizha oversees industry; Saltykov holds the position of Minister of Science, Higher Education, and Technology Policy; and Chubays heads the State Committee for Management of Property, including privatization.

State committees function at the same level of government as the ministries and are sometimes described as deputy ministries. They differ from ministries in that they supervise activities that cross the bounds of a single sector and, in this respect, are analogous to the federal advisory committees of the executive branch of the U.S. government. The function of the Russian state committees, however, appears to be more practical than advisory or policy-oriented. 
The committees listed on Figure 4 are the most active in environmental issues. Figure 4 does not include all state committees.

Most ministries and committees of the Russian Republic are reported to have some mechanism for dealing with environmental issues. EPG continually met with professed cooperation at the ministerial level to effect positive changes in the environmental policies of the Federation. Such cooperation is apart from the efforts of the Ministry of Ecology and Natural Resources. This ministry is sometimes viewed by the ministries it must monitor as superfluous, duplicating what the other ministries are already capable of doing.

The Ministry of Ecology and Natural Resources, known as Minpriroda, has an allencompassing mission for environmental concerns. Its primary functions are to ensure environmental protection and to monitor the use of natural resources. It is comparable to the U.S. Department of the Interior, the EPA, and the NOAA (without the U.S. Department of Fisheries) combined. It is inadequately funded and staffed for this range of responsibilities (Etkins 1992). The hierarchy of the leadership and committees of the Ministry of Ecology and Natural Resources is presented in Figure 5. A translation of the resolution authorizing the functions of this ministry in the area of environmental protection appears in Appendix F.

Both within the government system and among the general public, the effectiveness of the Ministry of Ecology and Natural Resources is questioned. The ministry and its associated roundtables and advisory groups are considered to be all talk and no action. There have been defections of staff from this ministry to more influential institutes. (EPG spoke with members of a special branch institute of the Academy of Sciences who had left the ministry because of their frustration.) The inability of the ministry to effect change is largely due to its insufficient support from the government, both financial and in terms of cooperation from other agencies.

The present Minister of Ecology and Natural Resources, V.I. Danilov-Danilyan, was chosen for his economic approach to environmental regulation as opposed to the administrative emphasis of past regimes (Etkins 1992). Danilov-Danilyan is a doctor of economic sciences, who specialized in the economics of energy and natural resources. He is a proponent of the "polluters pay" policy, meaning that industry is fined for exceeding emission standards and charged new, unsubsidized prices for raw materials and resources. Environmental laws are beginning to incorporate strict criminal codes for violators.

The huge network of committees associated with the Ministry of Ecology and Natural Resources is in the process of dismantling. Reforms associated with Perestroika lumped all of the all-union ministries having to do with environmental concerns into a single Ministry of.Ecology and Natural Resources. This grouping was never an effective unit and Western diplomatic sources report that the environmental committees continued to act as free agents. Like its predecessor Goskompriroda (the State Committee of Environmental Protection), the Ministry of Ecology and Natural Resources is plagued with internal conflicts. The committee on Geology and Use of the Interior has already officially broken away from the ministry, and others are reported to be anxious 


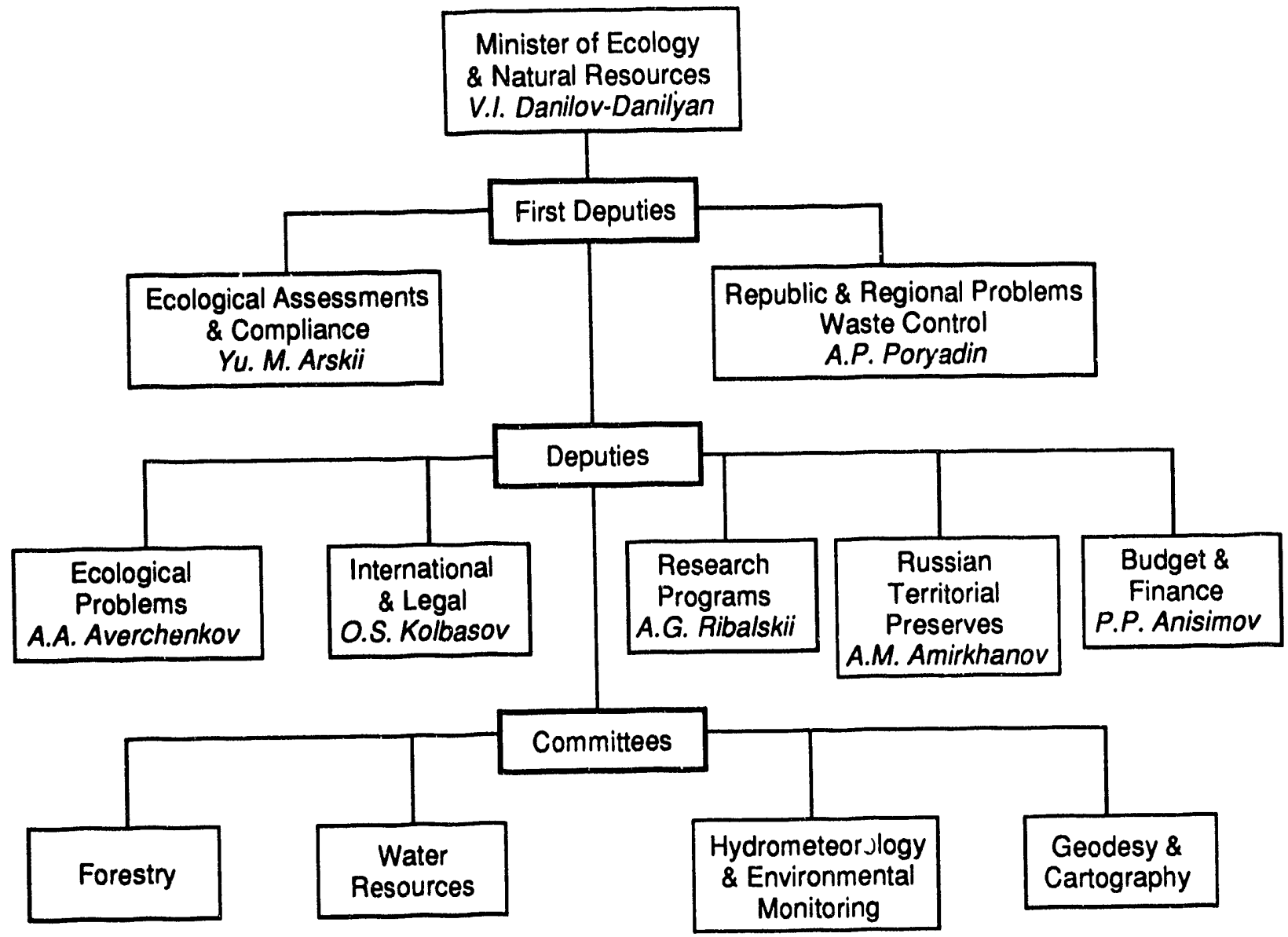

FIGURE 5 Structure of the Ministry of Ecology and Natural Resources (adapted from Etkins 1992)

to do the same. The extensive bureaucracy associated with the Ministry of Ecology and Natural Resources can be seen in Figure 6. A directory of names, addresses and telephone numbers for key ministry officials is presented in Appendix G.

The Ministry of Atomic Energy, known as Minatom, was established by presidential decree in January 1992 and is successor to the Ministry of Atomic Power and Industry (MAPI). This ministry is most closely analogous to the U.S. Department of Energy. V.N. Michailov, former Deputy Minister of MAPI, now serves as Minister of Minatom. Minister Michailov's closest U.S. counterpart is James Watkins, Secretary of Energy, although many of the nuclear arms issues that Minatom deals with are under the auspices of the U.S. Department of Defense.

A portion of the structure of Minatom is presented in Figure 7. This information was prepared from memory in July 1992 by Dr. E. Koudriavtsev, a senior scientist in the ministry, and should be considered an indication of the elements and concerns of the ministry, not an exact depiction of the present structure (Lehman 1992). The continued change within Minatom has made the ministry reluctant to issue any definite statement of its internal structure. 


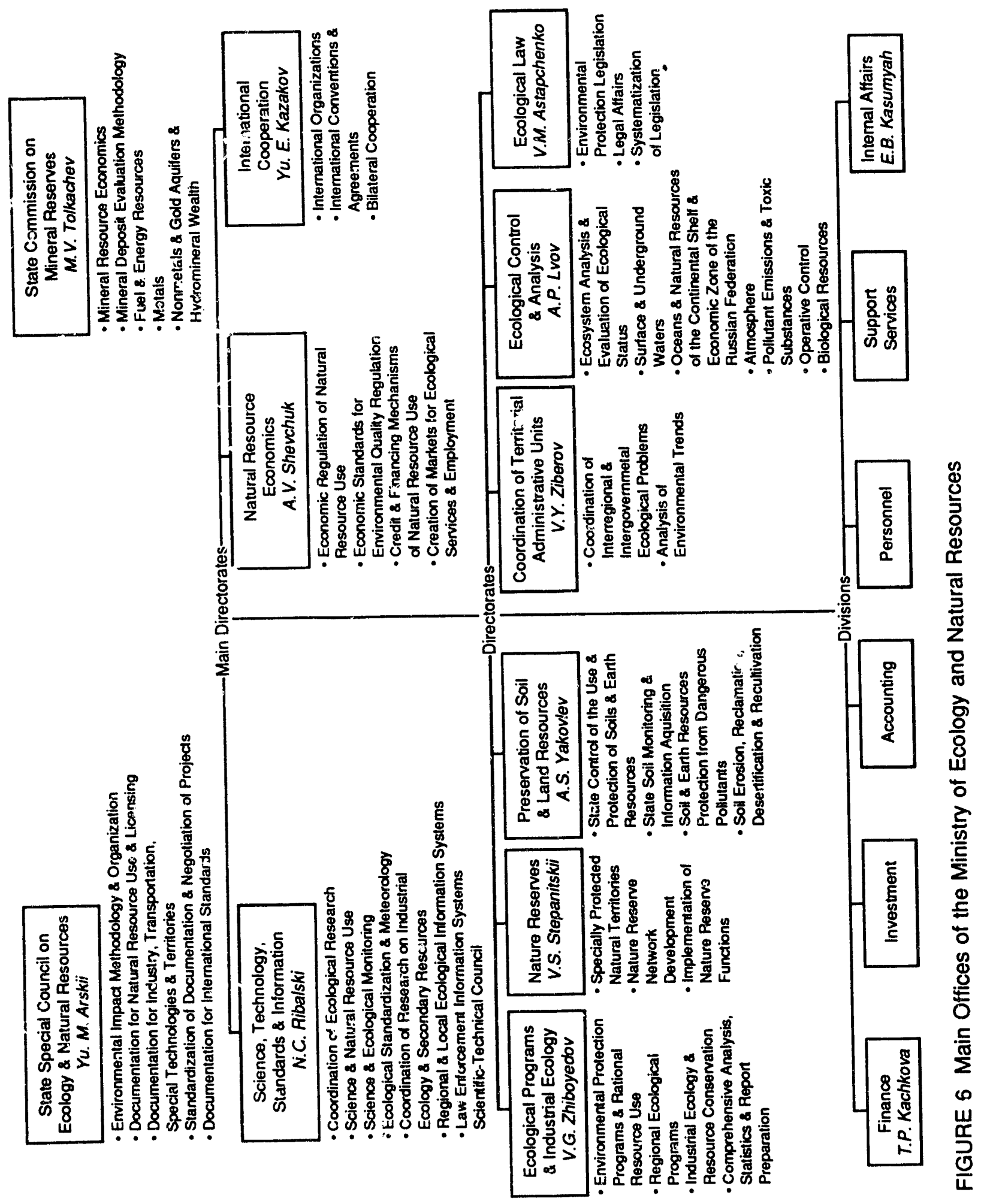




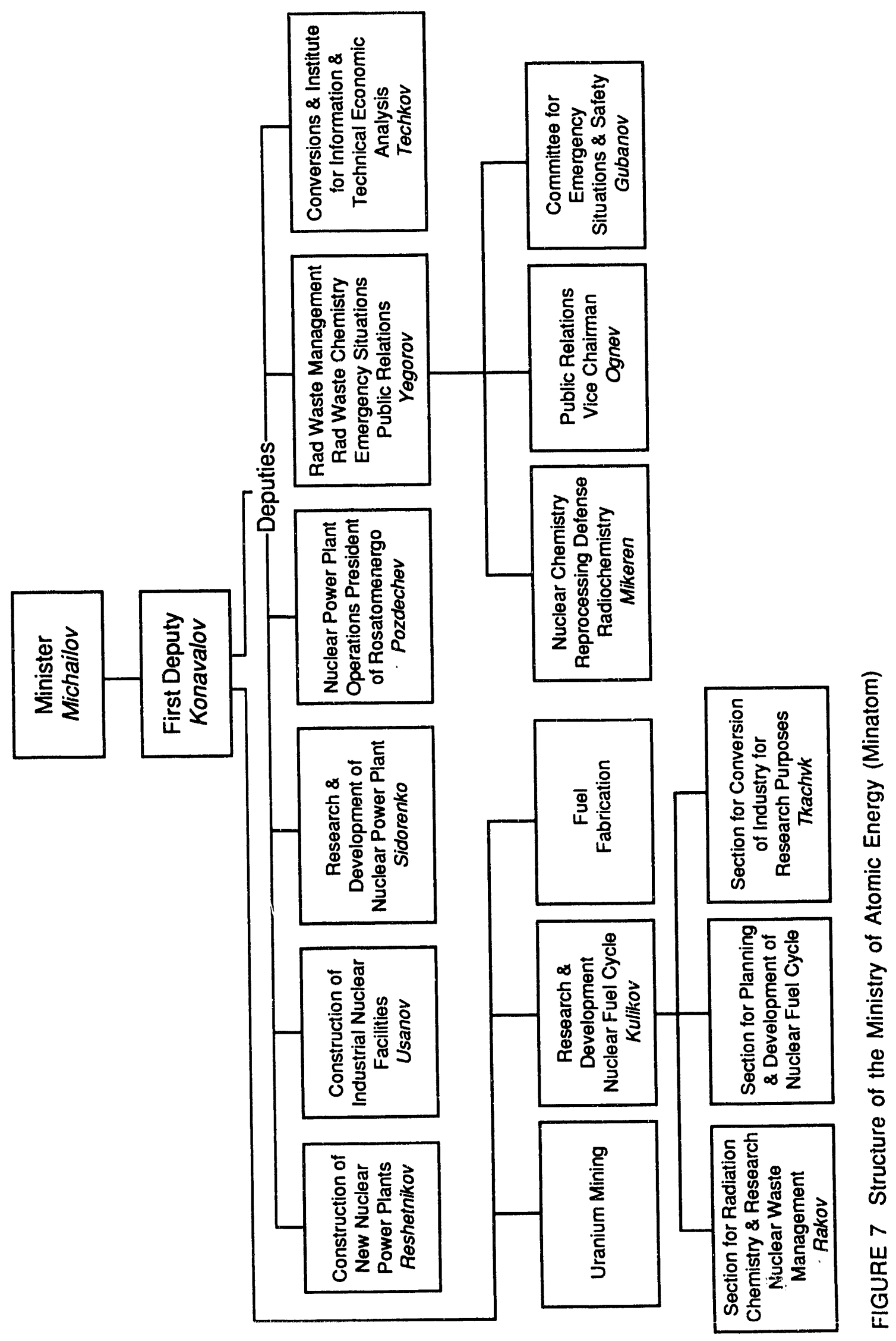


As reported by the Central Board of the Nuclear Society (1992), the mission of Minatom is to ensure nuclear and radiation safety; to oversee the functioning of enterprises and organizations within the nuclear complex; to conduct state scientific-technical investigations and structure policy relating to nuclear power; and to coordinate programs in the areas of nuclear arms, radioactive waste management, and nuclear complex conversion.

The ministry was newly organized to address management problems in the nuclearindustrial complex. Minatom is now specifically given authority to maintain a state monopoly for nuclear arms production and abolition. In addition, Minatom is responsible for implementing cooperative work among associated ministries and committees and establishing joint coordinating and advisory mechanisms to ensure safe nuclear power use. The January 1992 decree also makes provision for the economic independence of the enterprises involved in the nuclear power and fuel cycle programs, leaving the opportunity for private, commercial initiatives by scientists. Environmental and energy technologies with application to the U.S. Department of Energy needs niay be available through this Ministry.

The Ministry of Foreign Affairs is most involved in international exchanges and corresponds to the U.S. Department of State (Etkins 1992). Contact with the science and technical advisors in this ministry is one of the first steps in a traditional approach to technology transfer.

The Ministry of Science, Higher Education, and Technical Policy is most closely related to the U.S. National Science Foundation combined with the Office of Science and Technology Policy (Etkins 1992). This ministry administers the funding for a wide range of projects and agencies, including a portion of the budget for the Ministry of Ecology and Natural Resources and the Academy of Sciences. It was reported that of its 60 -billion-ruble budget, 1 billion is distributed to the Ministry of Ecology for science and technology programs.

The Ministry of Higher Education and Technological Policy also administers specific scientific and technical programs in the field of ecology. Participants in these programs are scientific institutes, universities, and university-based enterprises. Current programs in progress are Ecology of Russia, Geoecology of Russia, and the creation of a geochemical map of Russia. It is important to collaborate with this ministry for the development of environmental education and training programs. 


\section{Organization of the Russian Academy of Sciences and Other Research Institutes}

The Russian Academy of Sciences (RAS) is the most prestigious scientific organization in Russia, having been founded by Peter the Great in the eighteenth century. Although an integral part of environmental programs, the RAS is a nongovernmental organization. The government does provide funding for the RAS, but it cannot dictate which research projects to pursue. An outline of the structure of the RAS is presented in Figure 8.

The General Assembly, composed of all members of the RAS, meets about twice a year to establish basic policy and organization. The Presidium functions between meetings of the General Assembly and is the true executive authority. The Presidium currently has $\mathbf{4 4}$ members, all leading academicians, and includes the director of each research division. Decisions regarding which projects to undertake are made primarily by the scientists in the institutes and sanctioned by the Presidium. There are reportedly about 20 different divisions, supervising 360 institutes, and an additional 150 presidium institutes and organizations. The latter reportedly include councils, committees, and commissions related to ecological problems.

Scientific institutes appear to be the most stable organizations of the present system. Scientists are self-proclaimed conservatives when it comes to preserving the organizational constraints of the RAS. They are also explicit in proclaiming the innovative research and technology that result from this stability. It is estimated that $90 \%$ of the leadership and policymaking positions in government environmental programs are held by members of the RAS. Four vice-presidents of the RAS sit on the Supreme Ecological Soviet, which advises the Supreme Soviet Committee on Ecology.

A lump sum from the Russian budget is presented to the Presidium of the RAS for distribution to the various divisions and, ultimately, to the institutes. A special fund exists to finance 16 priority projects (including Mars and Global Change). In addition, the institutes can obtain funding by contracting their services to private enterprise or government ministries for specific projects. For instance, RAS is currently contracted by the Ministry of Atomic Energy to solve the problems of land disposal of radioactive waste. There is also a separate source of money from the Ministry of Science, Higher Education, and Technical Policy made available to all science programs through a competitive process much like that employed by the National Science Foundation in the United States.

The status and duties of scientific institutes vary widely. When a special project or issue is to be addressed, the responsibilities are granted to an institute that is created specifically for that purpose. Once established, the scope of an institute can alter significantly as it vies for government funding or contracts with industry. 


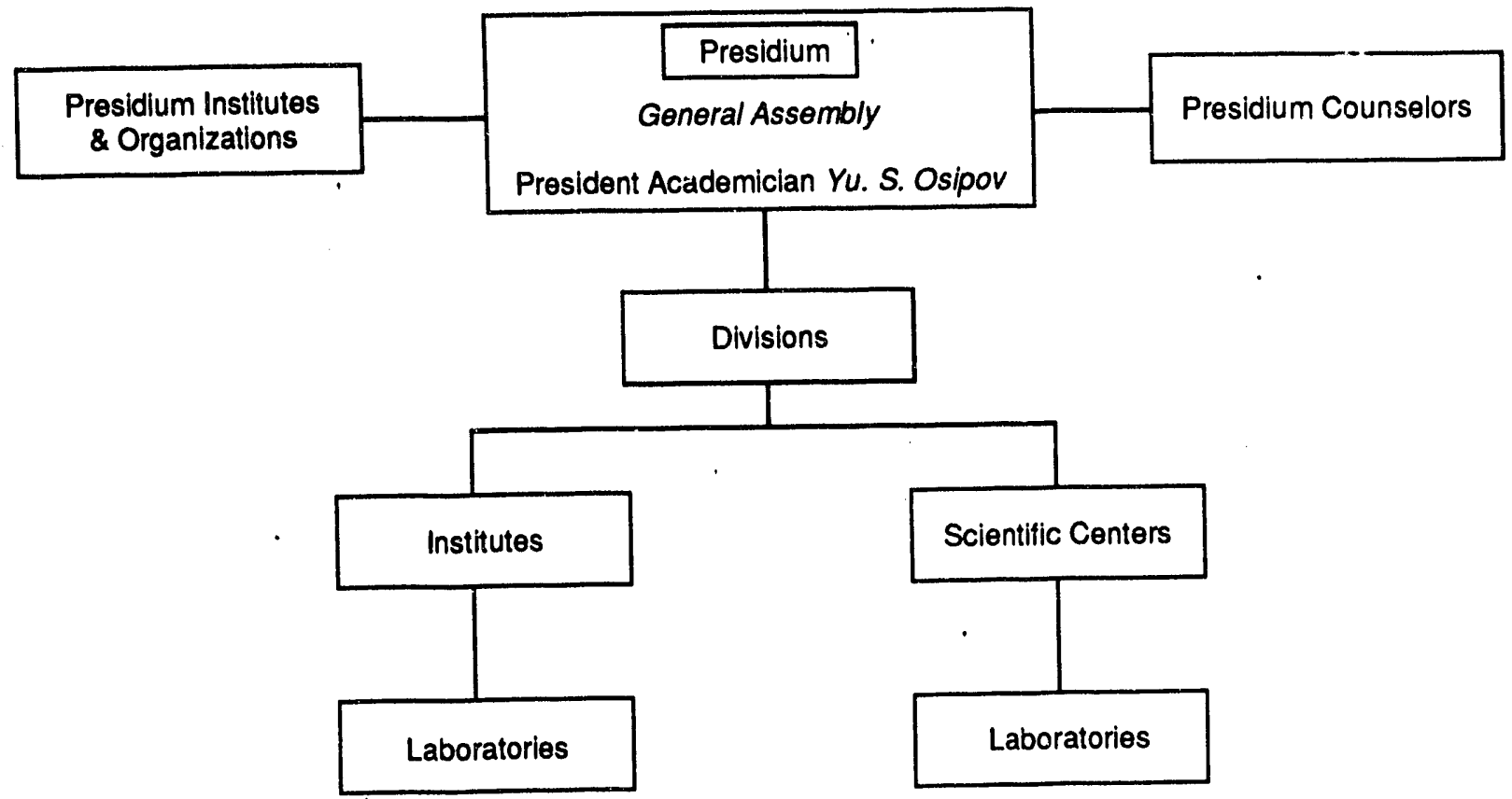

FIGURE 8 Structure of the Russian Academy of Sciences

Special branch institutes of the RAS usually function alongside the state committees and ministries to coordinate research in the more politically sensitive areas. They are now considered largely independent from the RAS and the ministries that have created and financed them in the past. An example of this type of institute is the Institute of Nuclear Safety, which was created in response to the accident at Chernobyl nuclear reactor in 1986. The Institute for Nuclear Safety maintains the official database on Chernobyl. The structure of this institute, which has recently been modified to a more "marketable" organization in order to pursue different funding sources, is presented in Figure 9 (Lehman 1990).

A reportedly new type of organization created by the RAS is the scientific center. These centers appear to have complex structures, sometimes incorporating commercial ventures.

The RAS is eager to get involved in cooperative international work that will generate funding. It is especially interested in ecological problems, but finds it difficult to have a relationship with the Ministry of Ecology because of that Ministry's constantly changing organization.

Another type of institute functions as an independent research and development center devoted to a specific area of concern. Such centers were primarily maintained by the military complex and have only recently been opened to international collaboration. The V.I. Kurchatov Institute of Atomic Energy, Moscow, is such an institute. Its independent status was officially declared on April 10, 1992. The institute is analogous to Sandia or Los Alamos National Laboratory in its scope and function. 


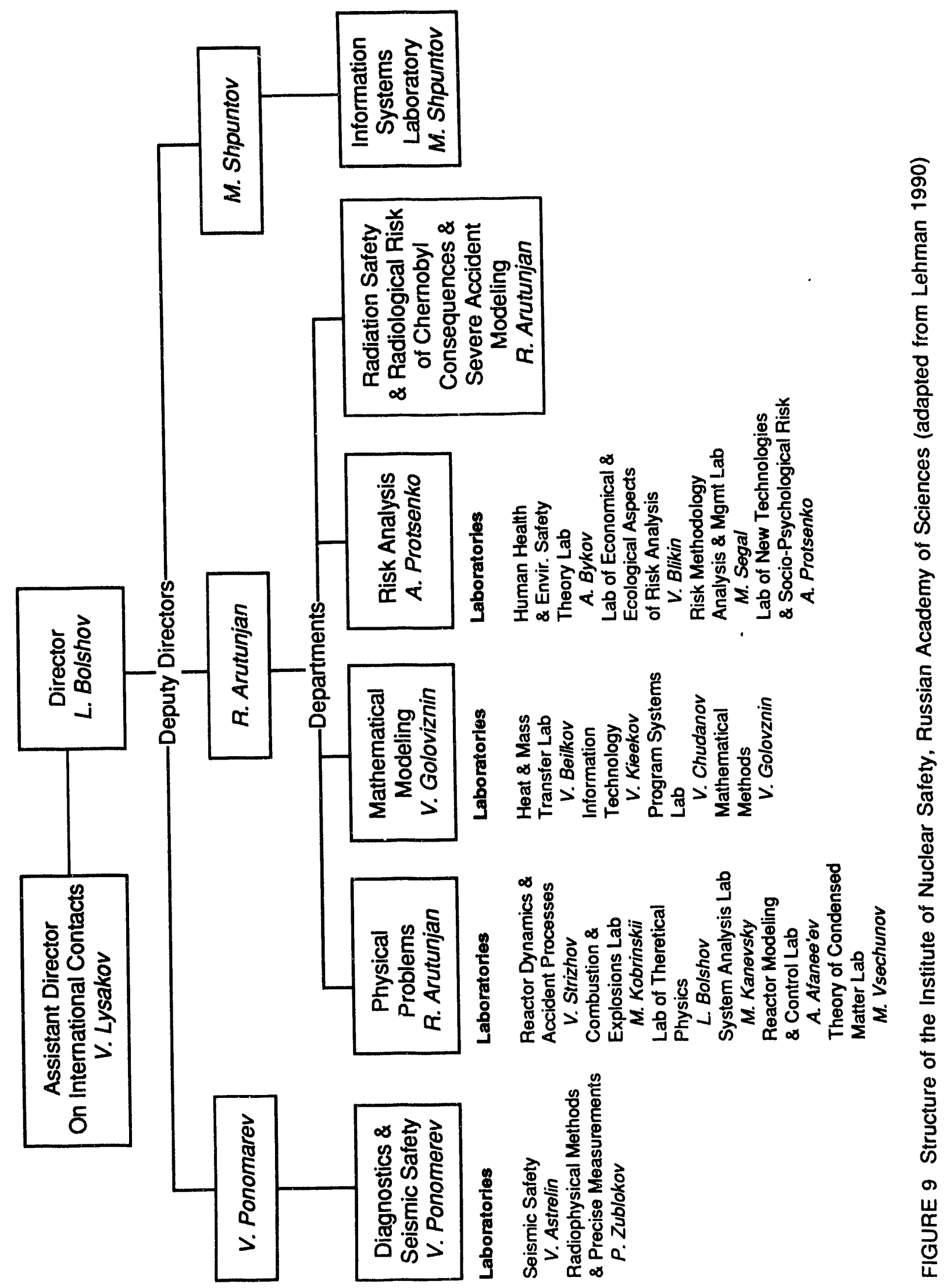


Kurchatov is said to exercise all the rights of a ministry or enterprise. Personnel are usually members of the RAS. Special financing for such institutes is provided in the Russian budget, but it is generally not considered adequate. Contracts can be negotiated with other institutes and commercial ventures.

Other institutes that function on the level of Kurchatov (although some maintain ties to the RAS) are the V.G. Khlopin Radium Institute, Leningrad (chemical separation, fuels reprocessing, geochemistry); All-Union Scientific Research Institute for Inorganic Materials, Moscow (disposal of high-level radioactive waste, properties of solid waste forms); Chemical Plant Research Institute, Sverdlovsk (vitrification pilot plants); Lebedev Physical Institute (laser-induced thermonuclear fusion); Institute of Physical Problems; and Landau Institute of Theoretical and Experimental Physics, Moscow. Hundreds of such institutes reportedly exist, but their continued operation is in jeopardy now that military patronage has been withdrawn. 


\section{Environmental Laws}

Environmental law is the driving force behind the environmental industry in the United States. It is not only a reflection of priority concerns, but an indicator of likely future development. In Russia, there is a growing emphasis on the enforcement of environmental legislation that is parallel to a similar movement that occurred in the United States during the 1970s. The effectiveness of Russian law will largely determine the growth of its environmental industry.

The field of environmental law in Russia has come into its own during the period of Perestroika (Robinson 1989). With Gorbachev's reforms came the concept of the "socialist lawgoverned state" and particular attention to the role of the Procuracy, the governmental organ mandated to oversee compliance to legislation (Barry and Barner-Barry 1991, p. 151). Expertise in environmental law is centered in the Sector on Ecological Law of the Institute of State and Law in the Academy of Sciences. O.S. Kolbasov, serving as a deputy to Minister Danilov-Danilyan in the area of international relations and environmental legislation, is a leading figure in the field of environmental law in Russia and has written many published works (see, for example, Kolbasov [1989]).

The law-governed state was officially endorsed in the Theses of the Nineteenth Party Conference in 1988 and has been elaborated primarily in two directions: the defense of individual rights and the role of the State in the Soviet system (Barry and Barner-Barry 1991, pp. 157-8). Individual rights are seen to be threatened by governmental powers, especially by the inordinately powerful executive branch. Strengthening of the legislature and the courts as instruments of the citizens in defense of their rights is considered necessary for a balance of power. The language of environmental law strongly reflects this new emphasis on individual rights.

Under Gorbachev, the Supreme Soviet Committee on Ecology and Rational Use of Resources had 50 members: 25 from the Congress and 25 from the Supreme Soviet. A group of 200 deputies formed an informal ecology block in the parliament (Green 1990). Under the present committee, a Supreme Ecological Soviet composec' mainly of scientists exists as a consulting body. No figures are available for the current struccure, but it is presumed that it mirrors the former Soviet committee organization. The Russian Supreme Soviet's Ecology Committee has operated largely independently of the Ministry of Ecology and Natural Resources or the Sector on Ecological Law of the Academy of Sciences' Institute of State and Law (Robinson 1991). Such compartmentalization within the bureaucracy was typical of the Soviet regime and continues to hinder progress toward new environmental management systems.

Environmental laws have been promulgated at all organizational levels of the USSR and Russia: the all-union level, the republican level, and the ministry and committee level. There is no systematic compilation of laws. Those passed at the level of the Supreme Soviet are listed on its 
Registry of Laws. It is also customary to publish state laws on the occasion of their ratification in one of the newspapers.

Although an impressive list of legislation exists, there has been no effective mechanism for enforcement of environmental law in the USSR or Russia. Primary polluters were from the powerful industrial or military sectors and immune to public or political attempts at restricting their activities. Laws that existed on record from the 1970s and 1980s were quite elaborate and covered all issues except hazardous waste management (Robinson 1991). With the dissolution of the USSR, republics have provided that the existing laws remain in force unless superseded by new republican laws. A political and judicial force that will ensure law enforcement still remains to be developed.

The new body of environmental law for the Russian Republic was published in the newspaper Rossiskaya Gazeta on March 3,1992. Appendix H provides an outline of the new laws. An accompanying decree of the Supreme Soviet ensures that these laws will supersede all past legislation. The economic emphasis of Minister Danilov-Danilyan is evident in the new provisions to extract heavy fines from transgressors of environmental legislation. Over 6 billion rubles in fines have already been collected. As summarized by Vera Mischenko and Olga Razbash, partners in Ecojuris, a new environmental law firm in Moscow, the new environmental law

...defines the basic principles of environmental protection and lays out the specific authority granted to governmental environmental protection agencies under the Ministry of Ecology and Natural Resources.

The law defines the rights of individuals and nongovernmental organizations (NGOs) in the economic regulation of environmental protection. It sets standards for industrial and construction projects, establishes the need for environmental assessments and requires the monitoring of manufacturing activities. It includes special regulations for dealing with environmental disasters and sets forth the laws governing nature reserves and other protected areas.

Large sections of the law deal with settling environmental disputes, determining inability and responsibility and assigning damages. It permits, for the first time, the assessment of major fines for environmental violations: for private citizens - from one to ten times the minimum monthly salary; for government officials - three to twenty times their salary; for organizations and corporations from 50,000 to 500,000 rubles.

Citizens and NGOs are given the right to demand complete and accurate information relating to environmental issues and to sue polluters for environmental damages. The law also includes administrative fines which may be levied against those who infringe on the environmental rights of individuals. (Mischenko and Razbash 1992) 


\section{Observations}

Like its Soviet predecessor, the Russian government is a huge and cumbersome bureaucracy. There is a tendency to create and consolidate committees into comprehensive working organizations, but practically, the system is compartmentalized and does not foster communication. Aggressive competition for scarce funding further inhibits interaction and cooperation.

The development of environmental and energy programs that can effectively treat the problems of the present Russian situation - extensive environmental degradation, lack of environmental regulations and the means to enforce them, lack of funding to administer programs, and a dearth of competent environmental professionals to implement policies of prevention - has been hindered by the structural constraints of the government system.

The present instability of the Russian Federation offers a rare opportunity to directly access the mechanisms for technology transfers. In many cases, individuals or newly formed private enterprises are acting as brokers for the research and technologies that were sponsored by the USSR. Determining who is a legitimate representative of the product is as important as validating the technology itself. Knowledge of such technologies resides in the scientific institutes, university laboratories, and the lower levels of government involved in research and development. Understanding the structure of Russian government, particularly the roles of individual scientific institutes and key investigators, will facilitate the proper negotiation for appropriate technologies.

Russian science and technology have historically been dominated by the military-industrial demands of the Soviet state. This relationship has promoted extensive research in many areas neglected by Western science. Traditionally, the Soviet system has lacked the ability to commercialize much of its research and development.

With the present restructuring of government goals and production processes, scientific centers have lost their traditional patrons and sources of funding. New markets are actively being sought to facilitate the demilitarization of Soviet science and technology. Commercialization of technologies that can be adapted for environmental remediation would bring welcome relief to the present economic crisis in the scientific community. With the tremendous environmental problems and breadth of laboratory research, Russia offers unique conditions for testing and screening environmental technologies. 


\section{Recommendations}

To efficiently determine which Russian technologies are best suited to the goals and needs of DOE-EM, EPG recommends undertaking the following tasks, which are consistent with the observations noted in this study:

- Delineate the structure of the Russian Academy of Sciences. Specific focus should be on special branch institutes to identify key projects and principal investigators involved in research. A detailed inventory of current and proposed technology development programs related to energy and environment should be recorded.

- Develop a list of key research institutes and define their areas of specialization.

- Develop comprehensive training programs for environmental professionals. The programs should provide hands-on learning opportunities in both field and management skills. Training can be coordinated with the implementation of projects suited to immediate Russian environmental needs. Facilities for training can serve as centers for technology identification, evaluation, and production.

- Create a directory of agencies and personnel in the Russian government specific to the energy and environmental sectors. The document should clearly link the correspondence between the United States and Russian agencies and personnel in the energy and environmental sectors.

- Detail current Russian environmental law and the legislative process. This report should emphasize how to influence the development - and support the enforcement - of environmental legislation.

- Establish an independent organization that can guide the distribution of U.S. funds to the Russian scientific community. This organization should have an established network in the research community, be cognizant of Russian culture, and know how to conduct business in the context of a transition economy. Such an organization would identify key personnel for proposed projects, administer contracts, and control the flow of funding in a manner that maximizes the efficiency of all resources.

- Compile a newsletter to track funding sources, projects, and significant changes in the energy and environmental sectors in Russia. This newsletter would inform DOE-EM of issues relevant to technology research and development. 
- Undertake the study of additional republics of the FSU in the detail proposed above. The first republic studied should be Ukraine, with attention to its radioactivity problems, heavy concentration of chemical production plants, and prestigious population of academicians and research institutes. The Baltic. states, with proximity to the European community and more advanced markets, and Kazakhstan, one of the largest republics hosting nuclear sites, would also be good candidates for such study.

- Provide a quarterly updating of this report and its dissemination to interested parties. 


\section{References}

Barry, D.D., and C. Barner-Barry, 1987, Contemporary Soviet Politics: An Introduction, 3rd ed., Prentice-Hall, Inc., Englewood Cliffs, N.J.

Barry, D.D., and C. Barner-Barry, 1991, Contemporary Soviet Politics: An Introduction, 4th ed., Prentice-Hall, Inc., Englewood Cliffs, N.J.

Central Intelligence Agency, 1992, "Russian Executive Branch," agency communique.

Etkins, R., 1992, "The Ministry of Ecology and Natural Resources of the Russian Federated Republic," internal memo distributed by the U.S. Department of Commerce, NOAA.

Feinberg, E., 1992, "Soviet Science in Danger," Physics Today, 45(5):30-38.

Feshbach, M., and A. Friendly, Jr., 1992, Ecocide in the USSR: Health and Nature under Siege, Basic Books, New York, N.Y.

Gelb, A., and C. Gray, 1991, The Transformation of Economies in Central and Eastern Europe, The World Bank, Washington, D.C.

Green, E., 1990, Ecology and Perestroika; Environmental Protection in the Soviet Union, The American Committee on the U.S.-Soviet Relations, Washington, D.C.

Kolbasov, O.S., 1989, "The Concept of Ecological Law," Connecticut Journal of International Law, 4:267-277.

Lehman, L., 1990, Presentation to the Advisory Committee on Nuclear Waste of the U.S. Nuclear Regulatory Commission, L. Lehman \& Associates, Inc., Burnsville, Minn.

Lehman, L., 1992, personal communication, L. Lehman \& Associares, Burnsville, Minn.

Mischenko, V., and O. Razbash, 1992, "New Environmental Law for Russia," Surviving Together, pp. 18-19, Spring.

Nuclear Society, Central Board, 1992, "On the Ministry of Atomic Energy of Russian Federation," Informatsionniy Bulleten, Yadernoe Obshchestvo, No. 4(17), p.1. 
Robinson, N.A., 1989, "Soviet Environmental Protection: The Challenge for Legal Studies," The Pace Environmental Law Review, 7:117-150.

Robinson, N.A., 1991, "Environmental Law of the USSR and Its Republics," in International Environmental Law and Regulation, J.A. Schlickman, T.M. McMahon, and N. van Riel, editors, Butterworth Legal Publishers, Salem, N.H., pp. USSR 1-USSR 32.

Sagdeev, R.Z., 1992, "SOS! Save Our Science!, " Physics Today, 45(5):22-28.

U.S. News \& World Report, 1992, "The Legacy of Soviet Communism: Poisoning Russia," April 13.

World Bank Annual Report, 1991. 


\section{Appendix A:}

\section{Bilateral Agreement on Cooperation in the Field of Environmental Protection}

(signed originally in May 1972)

U.S. Chairman

William F. Reily

U.S. Environmental Protection Agency
Russian Chairman

Victor I. Danilov-Danilyan

Ministry of Ecology and Natural Resources

\begin{tabular}{|c|c|c|}
\hline & Area & Lead U.S. Agencies* \\
\hline I. & Prevention of Air Pollution & EPA \\
\hline II. & Prevention of Water Pollution & EPA \\
\hline III. & $\begin{array}{l}\text { Pollution Associated with Agricultural Impacts on } \\
\text { Ecosystems }\end{array}$ & EPA \\
\hline IV. & Enhancement of the Urban Environment & EPA \\
\hline V. & Protection of Nature and Organization of Reserves & DOI (Natl. Park Service) \\
\hline VI. & Protection of the Marine Environment from Pollution & $\begin{array}{l}\text { DOT (U.S. Fish \& } \\
\text { Wildlife \& NOAA) }\end{array}$ \\
\hline VII. & Biological and Genetic Effects of Environmental Pollution & EPA \\
\hline VIII. & Influence of Environmental Changes on Climate & NOAA \\
\hline IX. & Earthquake Prediction & USGS \& NOAA \\
\hline $\mathbf{X}$. & Arctic and Sub-Arctic Ecosystems & EPA \& USGS \\
\hline $\mathbf{X I}$. & $\begin{array}{l}\text { Legal and Administrative Measures for Protection of } \\
\text { Environmental Quality }\end{array}$ & CEQ \\
\hline XII. & $\begin{array}{l}\text { Information, Education, and Training for Environmental } \\
\text { Protection }\end{array}$ & Various Universities \\
\hline XIII. & Pollution Prevention (Industrial Toxic Waste) & EPA \\
\hline \multicolumn{3}{|c|}{ Proposed: Environmental Economics } \\
\hline Ad & rking Group: Enviror & \\
\hline
\end{tabular}

\footnotetext{
* Abbreviations: EPA, Environmental Protection Agency; DOI, U.S. Department of the Interior; DOT, U.S. Department of Transportation; NOAA, National Oceanic and Atmospheric Administration; USGS, U.S. Geological Survey; and CEQ, Council of Environmental Quality.
} 


\title{
U.S. Participants in Working Groups I-XIII
}

\section{Area I Prevention of Air Pollution}

\author{
Frank A. Schiermeier \\ Director \\ Atmospheric Characterization and Modeling Division \\ EPAVAREAL \\ MD-80 \\ Research Triangle Park, NC 27711 \\ Tel: (919) 541-4542 \\ FAX: (919) 541-1379 \\ Yaroslaw Pekar \\ Program Analyst \\ EPAVAEERL \\ MD-49 \\ Research Triangle Park, NC 27711 \\ Tel: (919) 541-3995 \\ FAX: (919) 541-1536 \\ Frank Princiotta \\ Director \\ Air \& Energy Engineering Research Laboratory \\ EPAVAEERL \\ MD-60 \\ Research Triangle Park, NC 27711 \\ Tel: (919) 541-2822 \\ FAX: (919) 541-5227
}

\section{Area II Prevention of Water Pollution}

\author{
Valdas V. Adamkus \\ Regional Administrator \\ EPA/Region V \\ 77 W. Jackson Blvd. (R-19) \\ Chicago, IL 60604 \\ Tel: (312) 886-9851 \\ FAX: (312) 353-9196
}


Vacys Saulys

Technical Assistant

EPA/Region V

77 W. Jackson Blvd. (5HS-51)

Chicago, IL 60604

Tel: (312) 353-7648

FAX: (312) 353-9196

Rosemary Russo

Director

Environmental Research Laboratory-Athens

EPA/ERL

960 College Station Rd.

Athens, GA 30613

Tel: (404) 546-3500

FAX: (404) 546-2018

Richard A. Schoenger

Director

National Fisheries Contaminant Research Center

USF \& WS/NFCRC

4200 New Haven Rd.

Columbia, MO 65201

Tel: (314) 875-5399

FAX: (314) 876-1896

E. Timothy Oppelt

Director

Risk Reduction Engineering Laboratory

EPA/RREL

26 W. Martin Luther King Blvd.

Cincinnati, $\mathrm{OH} 45268$

Tel: (513) 569-7418

FAX: (513) 569-7787

Issiah Gelman, President

National Council of the Paper Industry for Air \& Stream

Improvement Inc. (NCASI)

260 Madison Avenue

New York, NY 10016

Tel: (212) 532-9000

FAX: (212) 779-2849 


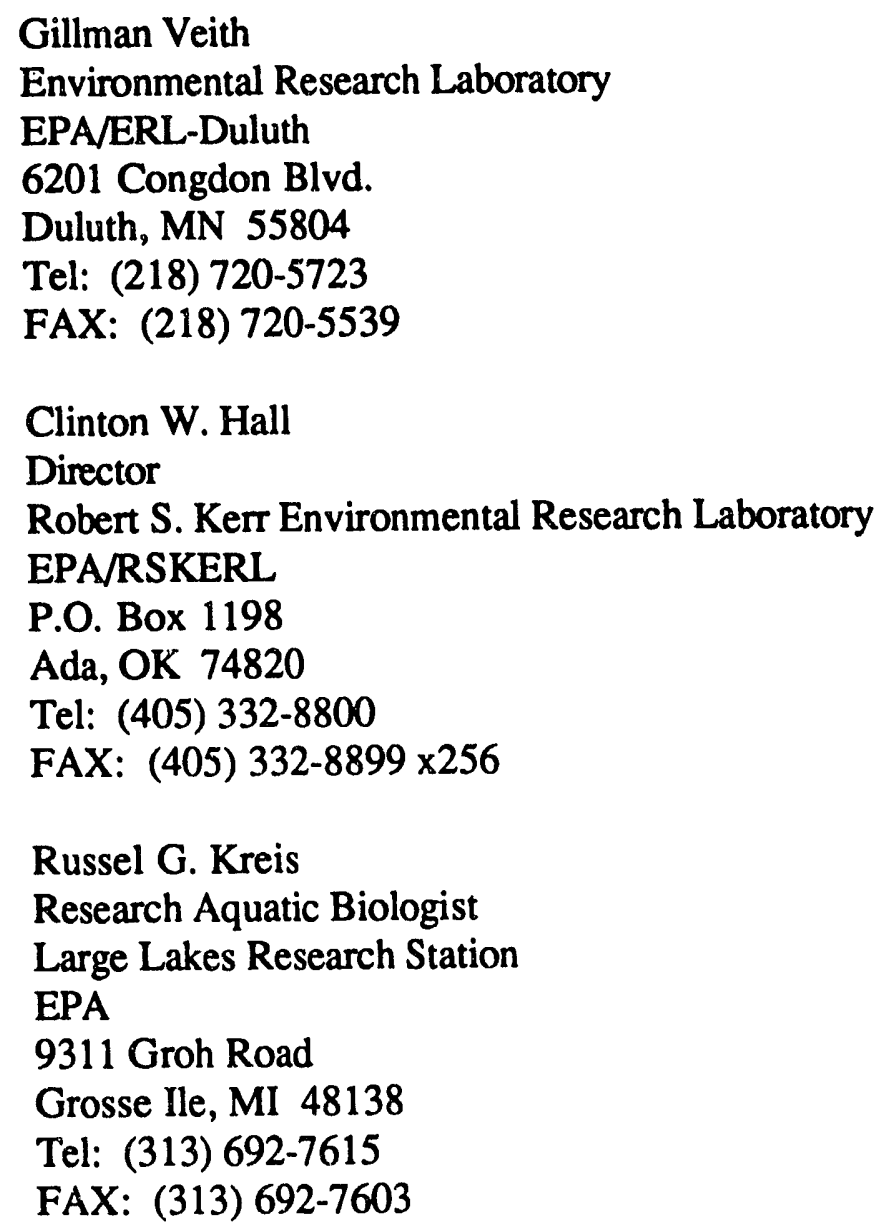

Area III Pollution Associated with Agricultural Impacts on Ecosystems

\author{
William Steen \\ Branch Chief-Biology \\ EPA/ERL \\ 960 College Station Road \\ Athens, GA 30613 \\ Tel: (404) 546-3103 \\ FAX: (404) 546-2018 \\ Reginald D. Noble \\ Chairman \\ Department of Biological Services \\ Bowling Green State University \\ 217 Life Sciences Building \\ Bowling Green, $\mathrm{OH} 43403$ \\ Tel: (419) 372-2332 \\ FAX: (414) 372-2024
}


Area IV Enhancement of the Urban Environment

\author{
Rick Cook \\ U.S. National Park Service (NPS) \\ 1100 L Street, NW, Room 2125 \\ Washington, DC 20013-7127 \\ Tel: (202) 343-7063 \\ FAX: (202) 343-7059
}

\title{
Area V Protection of Nature and Organization of Reserves
}

\author{
Steve Kohl \\ U.S. Fish \& Wildlife Service (USF \& WS) \\ Room 860-Arlington Square \\ Washington, DC 20240 \\ Tel: (703) 358-1762 \\ FAX: (703) 358-2849
}

\section{Area VI Protection of the Marine Environment from Pollution}

\author{
Captain Michael J. Donohoe \\ Chief, Marine Environmental Protection Division \\ DOT/USOG \\ Commandant (G-MEP) \\ 2100 2nd Street, SW \\ Washington, DC 20593 \\ Tel: (202) 267-0518 \\ FAX: (202) 267-4085 \\ Robert Dyer, Deputy Director \\ Radiation Studies Division \\ EPA/ORP \\ 401 M Street, SW (ANR-461) \\ Washington, DC 20460 \\ Tel: (202) 260-9639 \\ FAX: (202) 260-6918
}




\title{
Area VII Biological and Genetic Effects of Environmental Pollution
}

\author{
Michael Waters, Director \\ Genetic Toxicology Division \\ EPA/HERL \\ MD-68 \\ Research Triangle Park, NC 27711 \\ Tel: (919) 541-2534 \\ FAX: (919) 541-0694
}

\section{Area VIII Influence of Environmental Changes on Climate}

Robert Etkins

National Oceanic and Atmospheric Administration

NOAANCPO

1825 Connecticut Ave., NW, Suite 518

Washington, DC 20235

Tel: (202) 606-4360

FAX: (202) 606-4355

\section{Area IX Earthquake Prediction}

John Filson, Chief

Global Seismology \& Geomagnetism Branch

USGS

922 National Center

Reston, VA 22092

Tel: (703) 648-6785

FAX: (703) 648-6908

Virgil Frizzell

Assistant to the Chief

Office of Earthquakes, Volcanoes \& Engineering

USGS

905 National Center

Reston, VA 22092

Tel: (703) 648-6687

FAX: (703) 648-6717 


\title{
Area $X$ Arctic and Sub-Arctic Ecosystems
}

\author{
Reginald D. Noble \\ Chairman \\ Department of Biological Sciences \\ Bowling Green State University \\ 217 Life Sciences Building \\ Bowling Green, $\mathrm{OH} 43403$ \\ Tel: (419) 372-2332 \\ FAX: (419) 372-2024 \\ Jerry Brown \\ Co-Chairman Area X \\ P.O. Box 9200 \\ Arlington, VA 22219-0200 \\ Tel: (703) 525-5642 \\ FAX: (703) 235-3002 \\ James Devine \\ Assistant Director \\ Engineering Geology \\ USGS \\ 106 National Center \\ Reston, VA 22092 \\ Tel: (703) 648-4423 \\ FAX: (703) 648-4454
}

\section{Area XI Legal and Administrative Measures for Protection of Environmental Quality}

Jon Elkind

Policy Analyst, International Affairs

Council on Environmental Quality (CEQ)

722 Jackson Place, NW

Washington, DC 20503

Tel: (202) 395-5750

FAX: (202) 395-3874 
Dinah Bear

General Counsel

Council on Environmental Quality (CEQ)

722 Jackson Place, NW

Washington, DC 20503

Tel: (202) 395-5754

FAX: (202) 395-3874

\title{
Area XII Information, Education and Training for Environmental Protection
}

\author{
Arthur Sacks \\ University of Wisconsin, Madison \\ 206 Goodnight Hall \\ 1975 Willow Dr. \\ Madison, WI 53706 \\ Tel: (608) 262-9150 \\ FAX: (608) 262-0591
}

\section{Area XIII Pollution Prevention (Industrial Toxic Waste)}

\author{
Marvin Rubin \\ Chief, Energy Branch \\ Engineering \& Analysis Division \\ EPA/EOA \\ 401 M Street, SW (WH-552) \\ Washington, DC 20460 \\ Tel: (202) 260-7124 \\ FAX: (202) 260-7185 \\ Institute for Soviet American Relations (ISAR) \\ 1601 Connecticut Ave., NW, Suite 300 \\ Washington, DC 20009 \\ Tel: (202) 387-3034 \\ FAX: (202) 667-3291
}

Ad Hoc Eliza Klose, Executive Director 


\section{Appendix B:}

\section{Decree \\ of the President of the Russian Federation \\ Concerning Measures for the Reorganization of the Structure of the Apparatus of the President of the Russian Federation}

With the goal of improving the efficiency and practical interaction of state branches and to diminish expenses of government machinery of executive power of the Russian Federation, resolve:

\section{To abolish}

The State Commission under the President of the Russian Federation on economic problems connected with withdrawal of the Western group of troops from Federal Republic of Germany to the Russian territory;

The Council on the affairs of Federation and territories under the President of the Russian Federation;

The Working Group on military-strategic analysis under the President of the Russian Federation;

The Committee under the President of the Russian Federation on affairs of military servicemen and their families.

2. To transfer to the Government of Russia the following state committees, committees, and commissions under the President of the Russian Federation:

On matters of civil defense, extreme situations, and liquidation of the consequences of natural disasters;

On supervision of safe conduct of works in industry and mining control;

On standardization, metrology, and certification;

Sanitary epidemiological control;

Protection of economic interests of the Russian Federation; 
State awards in the fields of science and technology;

State awards in the fields of literature and art.

3. Reorganize the Secretariat of the President of the Russian Federation in the service of assistants of the President of Russia and Office of the President of Russia, with the cancellation of a number of staff.

4. Transform the post of State Secretary of the Russian Federation into the post of state secretary under the President of Russia.

5. Transform the post of State Counselor of the Russian Federation into the post of Advisor of the President of Russia. The quantity of the apparatus of the Advisor of the President of Russia is not to exceed five persons.

6. Exclude the combination of a post in the Administration of the President of the Russian Federation with any other post in state, commercial, and public organizations.

7. Create working apparatuses in the commissions on the affairs of citizenship, the affairs of pardon, and of state awards under the President of the Russian Federation, abolishing the corresponding departments in the structure of the State-and-Law Office of the President of the Russian Federation.

8. Charge the personnel department of the administration of the President of the Russian Federation (Rumyantsev, D.D.) to prepare within two weeks the Position concerning the Advisor of the President of Russia and suggestions on carrying into accordance with the present decree the staff and number of the apparatus.

Moscow, Kremlin

6 May, 1992

No. 465 


\section{Appendix C: \\ Prominent Members of the Committee of Fifteen Environmental Specialist Advisors}

Department of Ecological Policy

Energy Problems, Ecological Impact Assessment

Forest, Biodiversity

Department of Health

Department of Common Problems

Ecological Safety, Monitoring

Water Problems

Information Service

Service of Coordination Council
Zabelin, Sviatoslav

206-39-36

Nemenchinsky, Valery 206-39-93

Alekseyvsev, Gennady 206-23-68

Demin, Andrey

206-24-51

Revina, Svetlana

224-08-82

Lebedeva, Galina

224-09-25

Mitroplenova, Larissa

206-89-62

Rarasev, Vladimir

224-08-49 


\section{Appendix D: \\ Disposition \\ of the President of the Russian Federation \\ Concerning the Formation of a Coordinating Committee on Ecological Policy under the President of the Russian Federation}

With the goal of forming state ecological policy under conditions of the intensification of the utilization of natural resources during the transition to market relations:

1. To form a Coordinating Committee on Ecological Policy under the President of the Russian Federation.

To name as president of this committee, Yablokov, Aleksey Vladimirovich - State Counselor of the Russian Federation on ecology and public health.

2. The Coordinating Committee on Ecological Policy under the President of the Russian Federation should consist of

Minister of Ecology and Natural Resources of the Russian Federation (Deputy President of the Committee)

Minister of Health of the Russian Federation

Minister of Agriculture of the Russian Federation

Minister of Fuel and Energy of the Russian Federation

Minister of Science, Higher Education, and Technical Policy of the Russian Federation

Chairman of the State Committee of the Russian Federation on Social-Economic Development of the North

Chairman of the State Committee on Sanitary Epidemiological Control under the President of the Russian Federation

Chairman of the State Committee of the Russian Federation on the Social Protection of Citizens and Rehabilitation of the Territories Damaged from Chernobyl and Other Radiation Disasters 
Chairman of the State Committee on Control of Nuclear and Radioactive Safety under the President of the Russian Federation

Chairman of the State Committee under the President of the Russian Federation on matters of civil defense, extreme situations, and liquidation of the consequences of natural disasters

Chairman of the Committee on Land Reform and Land Resources under the Government of the Russian Federation

Chairman of the Committee on Living Conditions of the Ministry of Architecture, Building and Living Conditions of the Russian Federation - First Deputy Minister of Architecture, Building and Living Conditions of the Russian Federation

Chairman of the Committee on Water Resources of the Ministry of Ecology and Natural Resources of the Russian Federation

Chairman of the Committee on Forests of the Ministry of Ecology and Natural Resources of the Russian Federation

Chairman of the Committee on Geology and Mineral Resources of the Ministry of Ecology and Natural Resources of the Russian Federation

Chairman of the Committee on Hydrometeorology and Environmental Monitoring of the Ministry of Ecology and Natural Resources of the Russian Federation

Chairman of the Committee on Geodesy and Cartography of the Ministry of Ecology and Natural Resources of the Russian Federation.

3. To affirm the proposed position concerning a Coordinating Committee on Ecological Policy under the President of the Russian Federation.

4. For the securing of activities of the Coordinating Council on Ecological Policy under the President of the Russian Federation, to create a working group in the number of six people as a staff of the service of the State advisor of the Russian Federation on ecology and health.

B. Yeltsin

President

Russian Federation

4 January 1992 


\section{Appendix E: \\ Position Concerning the Coordinating Council on Ecological Policy under the President of the Russian Federation}

1. The Coordinating Counci: on Ecological Policy under the President of the Russian Federation is working out the proposal on the basic tendencies of governmental policy in the areas of the use of nature, the preservation of the environinent, and improvement of the ecological situation on the territory of Russia.

2. In its activities, the Coordinating Council of Ecological Policy under the President of the Russian Federation is directing the legislation of the Russian Federation and the present Position.

3. Basic tasks of the Coordinating Council on Ecological Policy under the President of the Russian Federation are

Consideration of the proposals of the ministries and departments pertaining to the conceptual bases of the policy in the areas of environment, ecological safety, and the exploitation of natural resources;

Working out of the agreed-upon proposals for the realization of the governmental ecological policy;

Coordinating the activity of the ministries, departments, and other organs of management on questions of ecological policy.

4. Coordinating Council on Ecological Policy under the President of the Russian Federation has the right

To receive from the organs of management essential information for the accomplishment of its functions;

To direct to the ministries, departments, and other organs of management recommendations on the realization of governmental ecological policy;

To serve communications of the representatives of the ministries, departments, and other organs of management on questions concerning the observance of ecological policy; 
To create expert commissions for study of the ecological situation in individual regions of Russia with the assistance of qualified specialists.

5. The decisions of the Coordinating Council on Ecological Policy under the President of the Russian Federation bear a recommending character, are formed by protocols of the sessions of the Council, and are directed at concerned ministries, departments, and other organs of management.

Confirmed

by the disposition of the President of the Russian Federation,

4 January 1992, No. 4-rp 


\section{Appendix F: \\ Government of the Russian Federation \\ Resolution, 7 July 1992, No. 468, \\ Concerning the Specially Authorized Organs of the State Government \\ in the Field of Environmental Protection}

The Government of the Russian Federation resolves

1. To establish that the Ministry of Ecology and Natural Resources of the Russian Federation and its local branches are specially authorized organs of state government in the field of environmental protection.

2. Until ratification of the Position of the Ministry of Ecology and Natural Resources of the Russian Federation, this Ministry is guided by the Position of the State Committee of the RSFSR on Ecology and Use of Nature, approved by resolution of the Ministry Council of the RSFSR, 14 June, 1991, No. 326.

E. Gaydar 


\section{Appendix G:}

\section{Main Offices of the Ministry of Ecology and Natural Resources}

State Ecological Expertise

State Commission for Reserves

Directorate of Science, Technology, Standards, and Information

Directorate of the Economics of Natural Resources

Directorate of Ecological Programs and Industrial Ecology

Directorate of Reserve Affairs

Directorate of Preservation of Soils and Land Resources

Directorate of the Organization of Ecological Control and Analysis

Directorate of the Coordination of Territorial Organs

Directorate of International Cooperation

Directorate of Ecological Law
Arskii, Yurii Michailovich Ul. Neshdanovoi, No. 11

Tel: 229-47-74

Tolkachev, Michail Vladimirovich Polyanka

Tel: 233-88-89

Ribalski, Nikolai Grigorevich

B. Gruzinskaya

Tel: 234-56-51

Shevchyk, Anatolii Vasilevich

Ul. Kedrova, No. 8/I

Tel: $125-62-71$

Zhiboedov, Victor Georgievich

Tel: 125-57-38

Stepanitskii, Vsevolod Borisovich

Tel: 125-61-33

Yakovlev, Aleksandr Sergeevich Tel: 124-58-51

Lvov, Anatolii Petrovich Ul. Nezhdanovoi, No. 11

Tel: 229-96-58

Ziberov, Valentin Evgenevich Ul. Nezhdanovoi, No. 11

Tel: 229-51-82

Kazakov, Yurii Efimovich

Tel: 229-98-45

Actapchenko, Vladimir

Michailovich

Tel: 229-83-16 
Leading Department Dealing with Communication by Means of Mass Information and Ecological Education

Financial-Economic

Investment

Accounting

Internal Affairs

Protocol Department
Samotesov, Evgenii Dmitrievich Tel: 229-73-54

Kachkova, Tatyana Petrovna

B. Gruzinskaya

Tel: 254-69-74

B. Gruzinskaya

Tel: 254-51-44

Tel: $254-70-22$

Kacymyan, Elena Vladimirovna Tel: 254-76-83

Ul. Nezhdanovoi, No. 11

Tel: 229-67-63 


\section{Appendix H:}

\section{Law of the Russian Soviet Federal Socialist Republic Concerning the Preservation of the Surrounding Natural Environment}

(3 March 1992)

Section 1. General principles

Section 2. Right of citizens to a healthy and pleasant environment

Section 3. Economic mechanisms of environmental protection

Section 4. Environmental quality standards

Section 5. State environmental assessments

Section 6. Environmental requirements in connection with the siting, planning, construction, rebuilding, or start-up of enterprises, installations, and other facilities

Seciion 7. Environmental requirements pertaining to the operation of enterprises, installations, and other facilities, or performance of other activities

Section 8. Environmental emergencies

Section 9. Specially protected natural territories and sites

Section 10. Environmental monitoring

Section 11. Environmental training, education, and scientific research

Section 12. Resolution of disputes in the area of environmental protection

Section 13. Liability for violation of environmental laws

Section 14. Compensation for damages caused by the violation of environmental law

Section 15. International cooperation in the field of environmental protection 

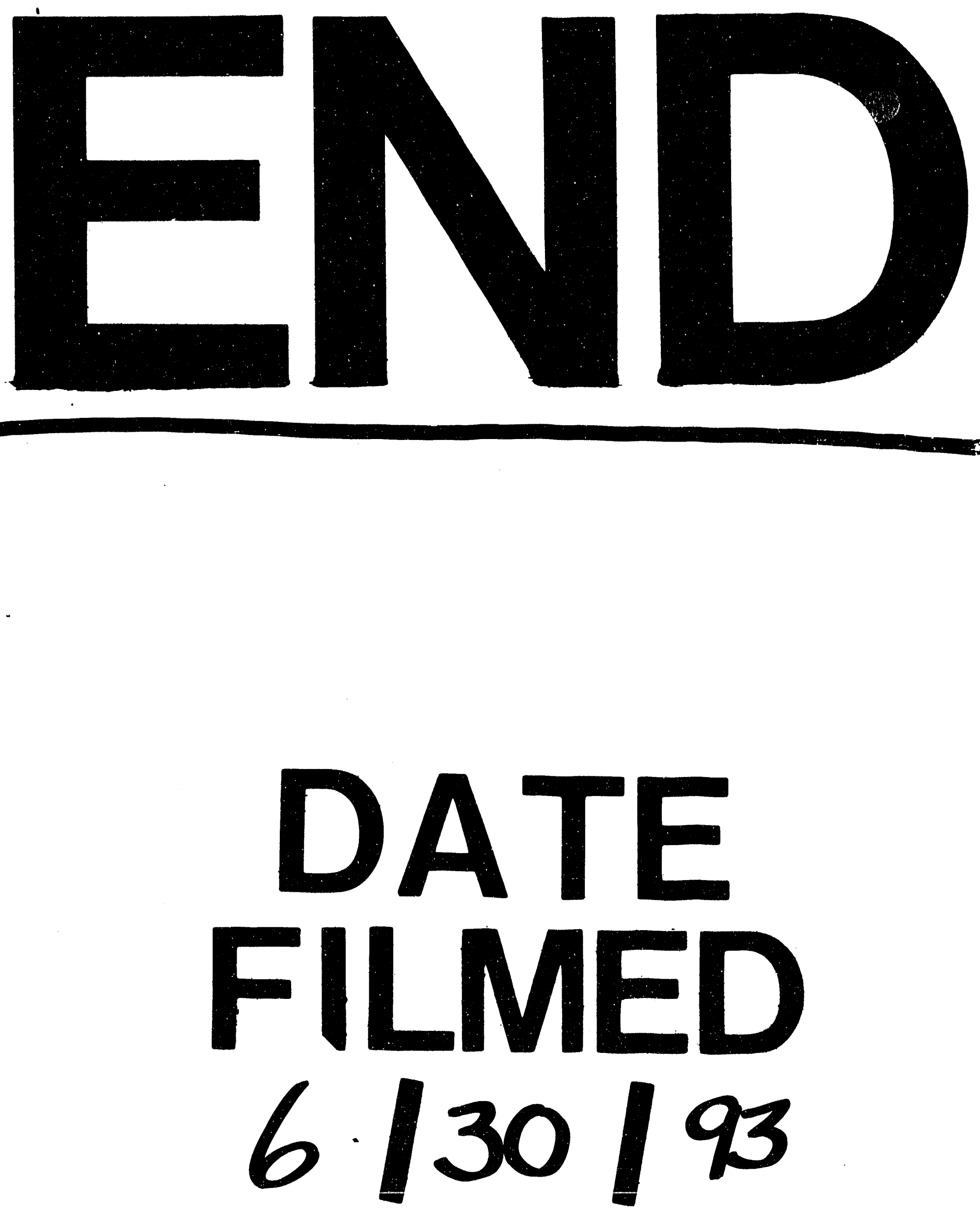
